\title{
Integrative systematics illuminates the relationships in two sponge-associated hydrozoan families (Capitata: Sphaerocorynidae and Zancleopsidae)
}

\author{
Davide Maggioni | ORCID: oooo-0003-0508-3987 \\ Department of Earth and Environmental Sciences (DISAT), University of Milano-Bicocca, \\ 20126 Milano, Italy \\ Marine Research and High Education (MaRHE) Center, University of Milano-Bicocca, \\ 1203o Faafu Magoodhoo Island, Republic of Maldives \\ davide.maggioni@unimib.it
}

Peter Schuchert | ORCID: oooo-0oo1-8195-8031

Muséum d'Histoire Naturelle, 1208 Geneva, Switzerland

Peter.Schuchert@ville-ge.ch

Roberto Arrigoni | ORCID: OOOO-0oo2-6825-6331

Department of Biology and Evolution of Marine Organisms (BEOM), Stazione Zoologica

Anton Dohrn, 80121 Naples, Italy

roberto.arrigoni@szn.it

Bert W. Hoeksema | ORCID: oooo-ooo1-8259-3783

Taxonomy, Systematics and Geodiversity Group, Naturalis Biodiversity Center, 2300 RA Leiden, The Netherlands

Groningen Institute for Evolutionary Life Sciences, University of Groningen, 9700 CC Groningen, The Netherlands

bert.hoeksema@naturalis.nl

Danwei Huang | ORCID: oooo-ooo3-3365-5583

Department of Biological Sciences, Tropical Marine Science Institute and Centre for Nature-based Climate Solutions, National University of Singapore, $11755^{8}$ Singapore,

Singapore

huangdanwei@nus.edu.sg

Giovanni Strona | ORCID: oooo-0oo3-2294-4013

Faculty of Biological and Environmental Sciences, University of Helsinki,

oo79o Helsinki, Finland

giovanni.strona@helsinki.fi 
Davide Seveso | ORCID: 0000-0oo1-7755-7067

Department of Earth and Environmental Sciences (DISAT), University of Milano-Bicocca, 20126 Milano, Italy

Marine Research and High Education (MaRHE) Center, University of Milano-Bicocca, 12030 Faafu Magoodhoo Island, Republic of Maldives

davide.seveso@unimib.it

Michael L. Berumen | ORCID: oooo-ooo3-2463-2742

Red Sea Research Center, Division of Biological and Environmental Science and Engineering, King Abdullah University of Science and Technology (KAUST), 23955-69oo Thuwal, Saudi Arabia

michael.berumen@kaust.edu.sa

Enrico Montalbetti | ORCID: oooo-ooo3-3932-1349

Department of Earth and Environmental Sciences (DISAT), University of Milano-Bicocca, 20126 Milano, Italy

Marine Research and High Education (MaRHE) Center, University of Milano-Bicocca, 12030 Faafu Magoodhoo Island, Republic of Maldives

enrico.montalbetti@unimib.it

Richard Collins | ORCID: oooo-0oo2-6225-444X

Independent researcher, Florida Museum of Natural History, 3215 Gainesville, Florida, USA rc6684@icloud.com

Paolo Galli | ORCID: oooo-0oo2-6065-8192

Department of Earth and Environmental Sciences (DISAT), University of Milano-Bicocca, 20126 Milano, Italy

Marine Research and High Education (MaRHE) Center, University of Milano-Bicocca, 12030 Faafu Magoodhoo Island, Republic of Maldives

paolo.galli@unimib.it

Simone Montano | ORCID: oooo-0oo2-6612-8731

Department of Earth and Environmental Sciences (DISAT), University of Milano-Bicocca, 20126 Milano, Italy

Marine Research and High Education (MaRHE) Center, University of Milano-Bicocca, 12030 Faafu Magoodhoo Island, Republic of Maldives

simone.montano@unimib.it

\begin{abstract}
An integrated approach using morphological and genetic data is needed to disentangle taxonomic uncertainties affecting the hydrozoan families Sphaerocorynidae and Zancleopsidae. Here we used this approach to accurately characterise species in these families, identify the previously unknown polyp
\end{abstract}


stages of the genera Euphysilla and Zancleopsis, which were originally described exclusively based on the medusa stages, describe a new sphaerocorynid genus and species, and assess the phylogenetic position of the two families within the Capitata. The monotypic genus Astrocoryne was found to be a synonym of Zancleopsis. Astrocoryne cabela was therefore transferred to the genus Zancleopsis as Zancleopsis cabela comb. nov. The new polyp-based genus and species Kudacoryne diaphana gen. nov. sp. nov. was erected within the Sphaerocorynidae. Both taxa are primarily based on genetic data, but the introduction of this new genus was made necessary by the fact that it clustered with the genera Heterocoryne and Euphysilla, despite showing Sphaerocoryne-like polyps. Interestingly, the species analysed in this work showed contrasting biogeographical patterns. Based on our data and literature records, some species appear to have a wide circumtropical range, whereas others are limited to few localities. Overall, these results lay the ground for future investigations aimed at resolving the taxonomy and systematics of these two enigmatic families.

\section{Keywords}

Sphaerocoryne - Zancleopsis - Euphysilla - Kudacoryne - Heterocoryne - life cycle

\section{Introduction}

Hydrozoan life cycles generally comprise three life stages, namely a larva (planula), a polyp, and a medusa, but exceptions to this pattern occur in many hydrozoan groups (Boero et al., 1992, 1997; Bouillon et al., 2006). Because medusae and polyps have different morphologies and require different collecting techniques, early naturalists often adopted two parallel classification systems for hydrozoans, due to the difficulties in linking the two life stages (Edwards, 1973; Boero, 1980). Later attempts were made to unify these classification systems (e.g., Rees, 1957; BrinckmannVoss, 1970), but the advent of molecular approaches, including DNA barcoding and molecular phylogenetics, has facilitated this task, allowing taxonomists to more easily link polyps and medusae previously assigned to different species, genera, or even families (e.g., Pyataeva et al., 2016; Schuchert et al., 2017; Schuchert, 2018). Notably, this integrative approach also revealed previously unsuspected relationships, such as for the hydrozoan Microhydrula limopsicola Jarms \& Tiemann, 1996, discovered to be an early stage of the staurozoan Haliclystus antarcticus Pfeffer, 1889 (Miranda et al., 2010), or the mysterious genus Dendrogramma Just, Kristensen \& Olesen, 2014, which is not classifiable into any metazoan phylum based on morphology alone (Just et al., 2014), but is now recognised as part of a siphonophore (O'Hara et al., 2016).

Recently, Schuchert \& Collins (2021) published a study on the hydromedusae of the Gulf Stream off Florida, providing DNA barcodes for many species previously not characterised genetically, and establishing the link between polyps and medusae for a number of species. Among others, they found that Euphysilla pyramidata Kramp, 1955 was genetically very similar to a Sphaerocoryne polyp from the Maldives, and that Zancleopsis dichotoma (Mayer, 1900) was closely related to Astrocoryne cabela Maggioni et al., 2017 from the Maldives and the Red Sea, for which only the polyp and the young medusa are currently known (Maggioni et al., 2017). Sphaerocoryne Pictet, 1893, Astrocoryne Maggioni et al., 
2017, Heterocoryne Wedler \& Larson, 1986, and Euphysilla Kramp, 1955 currently constitute the family Sphaerocorynidae Prévot, 1959, whereas Zancleopsis Hartlaub, 1907 and Dicnida Bouillon, 1978 are the two genera of the family Zancleopsidae Bouillon, 1978. Both families are in the suborder Capitata, even though the phylogenetic relationships with the other Capitata members were assessed only for the Sphaerocorynidae (Nawrocki et al. 2010; Maggioni et al. 2017, 2018, 2021). Species in this latter family are characterized by a rather complex taxonomic history, exacerbated by the incomplete knowledge of the life cycles of some species and by nomenclatural issues (see Calder, 2010; Schuchert, 2010). This is the case, for example, of the genus Sphaerocoryne, currently comprising three valid species, the type species Sphaerocoryne agassizii (McCrady, 1859), Sphaerocoryne bedoti Pictet, 1893, and Sphaerocoryne peterseni Bouillon, 1984, with the latter known only from the medusa stage (Bouillon, 1984). Following Calder (2010), if all species are congeneric, then Sphaerocoryne will become a junior synonym of Corynetes Haeckel, 1879. However, if $S$. agassizii is not congeneric with the other two species, it will become Corynetes agassizii, whereas the genus Sphaerocoryne will remain valid for $S$. bedoti and S. peterseni. As already highlighted by Schuchert (2010), only a genetic assessment can eventually clarify the status of the two generic names.

Sphaerocorynid polyps live generally in association with sponges, although some exceptions are known, and the main differences among genera rely on the tentacle organisation (Maggioni et al., 2017). Other differences are in the reproductive stage, with fixed eumedusoids in Heterocoryne and free medusae in Sphaerocoryne, Astrocoryne, and Euphysilla. However, the adult medusa of Astrocoryne and the polyp stage of Euphysilla were unknown until now.
The family Zancleopsidae currently comprises six Zancleopsis and one Dicnida species, all of which were described based on the medusa stage alone, and the polyps remain unknown (Wang et al., 2016). The phylogenetic position of the family and the internal relationships have never been investigated thoroughly, but a recent phylogenomic work placed the species Zancleopsis tentaculata Kramp, 1928 within Capitata, together with Millepora and Pennaria (Bentlage \& Collins, 2021).

In this work, several sphaerocorynid and zancleopsid polyps and medusae were analysed using an integrative approach in order to disentangle the taxonomy and systematics of the two families. Specifically, morphological and genetic analyses were performed to assess the diversity and the phylogenetic relationships of the two families, and to eventually link polyp and medusa stages of species with partially unknown life cycles.

\section{Material and methods}

Sampling of the hydroids was carried out by snorkelling ( $0-5 \mathrm{~m}$ depth) and diving (5-30 m depth) between March 2008 and June 2020 in several localities across the Red Sea, the Indo-Pacific, and the Atlantic Ocean (supplementary table $\mathrm{S} 1$ ). Small fragments of the host sponges (or other substrates) and associated hydroids were collected. Identification of the host sponge to the species or genus level was possible only in a limited number of samples (supplementary table $\mathrm{S} 1$ ). Where possible, live animals were reared in constantly oxygenated bowls filled with seawater, at room temperature, under artificial light, and fed with Artemia nauplii to observe medusa buds maturation and release. Animals were anesthetised with menthol crystals and directly observed and photographed under a Leica 
EZ4 D stereo microscope and a Zeiss Axioskop 40 compound microscope. Subsequently, polyps were detached from their substrate and fixed in both 99\% ethanol for molecular analyses and 10\% formalin for further morphological analyses. All measures were taken using the ImageJ 1.52p software. Medusae were collected, photographed, and fixed as described by Schuchert \& Collins (2021). Voucher material was deposited at the Muséum d'Histoire Naturelle (Geneva, Switzerland) and is indicated by the catalogue number MHNGINVE-\#\#. Other acronyms for voucher material are MSNM-Coe-\#\# (Museo Civico di Storia Naturale, Cnidaria Collection, Milano, Italy) and UF-\#\#\# (Florida Museum of Natural History, Gainesville, Florida, USA).

Total genomic DNA was extracted from ethanol-fixed samples using the protocols described in Maggioni et al. (2020a) and Schuchert (2005). Briefly, DNA was extracted from a single polyp or medusa by digesting the specimen in a mixture of proteinase $\mathrm{K}$ and MilliQ water in the first case, or following the CTAB protocol (Coffroth et al., 1992) in the second case. Six molecular markers were amplified using the primers and protocols described in Maggioni et al. (2020b), including portions of the mitochondrial large ribosomal rRNA gene (16S rRNA), cytochrome oxidase subunit I gene (COX1), cytochrome oxidase subunit III gene ( $\left.\operatorname{cox}_{3}\right)$, and nuclear small ribosomal RNA gene (18S rRNA), large ribosomal RNA gene (28S rRNA), and internal transcribed spacer region (ITS; including partial ITS1, 5.8S, and partial ITS2 regions). The success of polymerase chain reactions (PCRs) was checked through 1.5\% agarose electrophoretic runs and PCR products were then purified with Illustra ExoStar (GE Healthcare) and sequenced in both directions by Macrogen Europe (Amsterdam, The Netherlands).

Geneious 6.1.6 (Kearse et al., 2012) was used to check, correct, and assemble the obtained chromatograms and to assess the presence of open reading frames in protein-coding genes. All consensus sequences obtained in this study were deposited in GenBank with the accession numbers MZ457346-MZ4574O8, MZ457564-MZ457713, MZ457741-MZ457898, and MZ463764-MZ463844, as listed in table S1. Sequences were aligned using MAFFT 7.110 (Katoh \& Standley, 2013) with the E-INS-i option, after adding outgroup sequences following Maggioni et al. (2017, 2018) (supplementary table S1). Additionally, except for the protein-coding genes, the alignments were run through Gblocks (Castresana, 2000; Talavera \& Castresana, 2007) using the 'less stringent' settings to remove poorly aligned regions (supplementary table S2). All alignments were analysed separately and then concatenated using Mesquite 3.2 (Maddison \& Maddison, 2006). Substitution models were determined using jModelTest2 (Darriba et al., 2012) and PartitionFinder 1.1.1 (Lanfear et al., 2012) for the single-locus and multi-locus datasets, respectively, using the Akaike Information Criterion (AIC) (supplementary tables $\mathrm{S}_{2}$ and $\left.S_{3}\right)$. Phylogenetic reconstructions were performed using maximum parsimony (MP), maximum likelihood (ML), and Bayesian inference (вI) using both single- and multi-locus datasets. MP analyses were performed using PAUP 4.ob1o (Swofford, 2003) with heuristic searches stepwise addition and tree-bisection reconnection branch swapping. Node support was assessed using 1,00o bootstrap replicates with randomly added taxa. ML analyses were run in RAxML 8.2.12 (Stamatakis, 2014), using $\mathrm{GTR}+\mathrm{G}$ as the substitution model, and with 1,000 bootstrap replicates. BI analyses were run using MrBayes 3.2.6 (Ronquist et al., 2012), and two independent runs for four Markov chains were conducted for 50 million generations, with trees sampled each 5 ,oooth generation. A species tree was also obtained using *BEAST (Heled \& Drummond, 2009) in BEAST 
2.2.o (Bouckaert et al., 2014), considering mitochondrial loci as a single partition, and keeping nuclear loci separate. Yule process prior, together with a linear and constant-root population-size model were used, and each analysis was run for $10^{8}$ generations, sampling each 10,oooth generation. For both MrBayes and BEAST analyses, parameter estimates and convergence were checked using Tracer 1.6 (Rambaut et al., 2014), and the burn-in was set at $25 \%$. All phylogenetic analyses were run on the CIP RES server (Miller et al., 2010). Finally, MEGA X (Kumar et al., 2018) was used to compute genetic distances within and among the obtained clades, calculated as \% uncorrected $p$-distances with 1,0oo bootstrap replicates.

To confirm the morphology-based species boundaries, DNA-based species delimitation approaches were applied to the single-locus 16S rRNA dataset. Prior to performing the analyses, identical sequences were collapsed into representative sequence types using FaBox (Villesen, 2007), following Fontaneto et al. (2015). The distance-based Assemble Species by Automatic Partitioning (ASAP; Puillandre et al., 2021) method was run on the website 'asap web' (https://bioinfo.mnhn.fr/ abi/public/asap/) using all the three available models ( $p$-distance, Kimura 2-parameter, and Jukes Cantor) and considering only the partitions showing the lowest asap-score. The tree-based Poisson Tree Process (PTP) and Generalised Mixed Yule Coalescence (GMYC) approaches were also used. Specifically, a 16S rRNA ML tree was obtained as described above and was used as input for multiple-threshold PTP analyses (mtPTP: Kapli et al., 2017) on the website 'mPTP Webservice' (https://mptp.hits.org). For GMYC analyses, a 16S rRNA ultrametric Bayesian tree was obtained with BEAST 1.8.2 (Drummond et al., 2012), setting a coalescent tree prior and an uncorrelated lognormal relaxed clock. Three replicate analyses were run for $10^{8}$ million generations, sampling trees every 10,000 generations, and were combined using LogCombiner 1.8.2 (Drummond et al., 2012 ) with a burn-in set to $25 \%$. A maximum clade credibility tree was then obtained using TreeAnnotator 1.8.2 (Drummond et al., 2012). GMYC analyses were run in the R environment (R Core Team, 2020), using the single-threshold (stGMYC; Pons et al., 2006) and bGMYC (Reid and Carstens, 2012) implementations, using the packages 'Splits' (Ezard et al., 2009), 'Ape' (Paradis et al., 2004), and 'bGMYC' (Reid and Carstens, 2012).

DNA diagnostic characters were searched for each genus in the family Sphaerocorynidae, given the difficulties in defining generic diagnoses based on morphology, using the package QUIDDICH (Kühn \& Haase, 2O2O) in the R environment (R Core Team, 202O). Specifically, character attributes (i.e., single nucleotides) present in all members of a defined clade but absent in members of other clades were searched, and the analyses were run for each molecular marker, apart from ITs since it showed a high number of insertions or deletions. It must be specified that this approach provide diagnostic characters that are provisional, since increasing the geographic scale and the sampling effort could introduce variability in the dataset, and therefore influence the reliability of some of the detected diagnostic characters. The alignments used to detect DNA diagnostic characters were deposited at www.figshare.com (https://doi.org/10.6o84/ m9.figshare.14932662) and the diagnostic positions refer to reference sequences belonging to S. bedoti (MHNG-INVE-O137431), with the following GenBank accession numbers: MZ457614 for 16S, MZ457396 for COX1, MZ463827 for CoX3, MZ45788o for 18S, and MZ457801 for 28S. When diagnostic positions differed between reference sequences and alignments (due to the presence of gaps in the reference sequences), the position in the alignments was also reported in parentheses. 
To visualise possible geography-related genetic structure within selected clades, median-joining haplotype networks based on the most complete single-locus dataset (16S rRNA) were built using the software PopART 1.7 (Leigh \& Bryant, 2015). Finally, maps were produced in Python using the Matplotlib Basemap Toolkit (Hunter, 2007). All images were edited with CorelDRAW X7.

The present work is registered in ZooBank under: http://zoobank.org/urn:lsid:zoobank. org:pub:86E35163-o8o8-44CD-A1F8-D7F$\mathrm{B} 6{ }_{7} \mathrm{EFC1B}$.

\section{Results}

A total of 84 samples (supplementary table $\mathrm{S} 1$ ) were analysed from the studied localities (fig. $1 \mathrm{~A})$, allowing the morpho-molecular assessment of five species and four genera belonging to the Sphaerocorynidae (i.e., Sphaerocoryne bedoti, Kudacoryne diaphana gen. nov. sp. nov., Euphysilla pyramidata, Euphysilla sp., and Heterocoryne caribbensis) and three species and one genus of the Zancleopsidae (i.e., Zancleopsis dichotoma, Zancleopsis cabela comb. nov., and Zancleopsis sp.). A phylogeny reconstruction of the two families, based on six loci, is presented in the 'Molecular results' section, whereas taxonomic accounts for each species are reported in the 'Taxonomy' section, including the establishment of Kudacoryne diaphana gen. nov. sp. nov. and Zancleopsis cabela comb. nov. Finally, the distribution of each species and the genetic structure of selected species across the sampling localities are addressed in the 'Distribution and geographic structure' section.

\section{Molecular results}

The single- and multi-locus phylogeny reconstructions were broadly concordant in recovering all the investigated species as monophyletic groups, with a few exceptions in single-locus analyses based on nuclear loci (fig. 1b, supplementary figs. $S_{1}$ and $S_{2}$ ). As shown in the multi-locus phylogenetic tree and in the species tree (fig. $1 \mathrm{~B}, \mathrm{C}$ ), both the Sphaerocorynidae and Zancleopsidae were demonstrated to be highly supported and monophyletic sister groups. Moreover, the two families were placed as sister group to a clade composed of the families Cladocorynidae Allman, 1872, Zancleidae Russel, 1953, Asyncorynidae Kramp, 1949, Milleporidae Fleming, 1828, and Solanderiidae Marshall, 1892, similarly to previous analyses focusing on the Cladocorynidae (Maggioni et al., 2021) (fig. 1B). Within the Sphaerocorynidae, Sphaerocoryne bedoti was recovered as the sister group to all other species, whereas Kudacoryne diaphana gen. nov. sp. nov. (see 'Taxonomy' section) was sister to the clade Euphysilla + Heterocoryne, even though the latter showed low ML and MP bootstrap values (figs. $1 \mathrm{~B}, \mathrm{C}$ ). The genetic data enabled linking of the polyp and medusa stages of $E$. pyramidata, since medusa-based sequences from Florida consistently clustered with polyp-based sequences from Indian Ocean and Caribbean localities.

Within the Zancleopsidae, genetic data also helped establish the link between the polyp and medusa stages of two species. Specifically, an Astrocoryne-like colony from Singapore was linked to Zancleopsis dichotoma medusae from Florida. Similarly, sequences of Astrocoryne cabela polyps from the Maldives and Red Sea clustered with medusae from Florida, provisionally ascribed to $Z$. dichotoma by Schuchert \& Collins (2O21), requiring the synonymisation of Astrocoryne with Zancleopsis. Schuchert \& Collins (2021) divided their $Z$. dichotoma medusae from Florida into two morphs which also showed high genetic divergence and suggested the possible presence of two species, namely a small morph, herein linked to 
A)

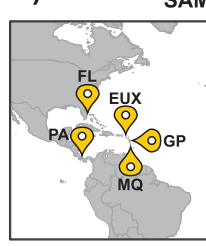

FL Florida PA Panama
EUX Sint Eustatius

c)

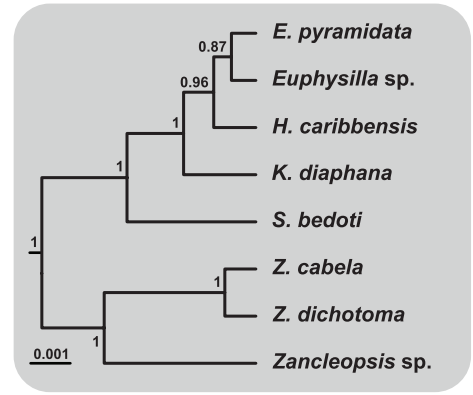

B)

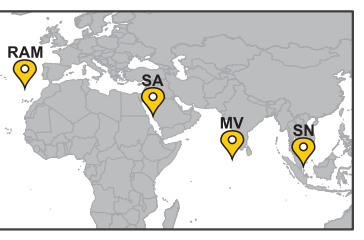

GP Guadeloupe SA Saudi Arabia MQ Martinique MV Maldives RAM Madeira

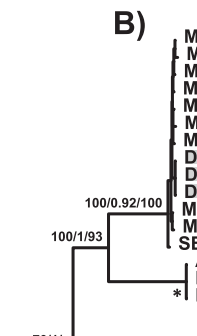

MA212 MV MA328 MV MA219 MV MA202 MV MA204 MV MA205 MV DNA1584 FL

Euphysilla

pyramidata DNA1607 FL MA177 MV MA210 MV AL 04 MO BT003 PA BT004 PA

\section{Euphysilla sp.}

SE005 EUX SE006 EUX SE008 EUX

Heterocoryne caribbensis

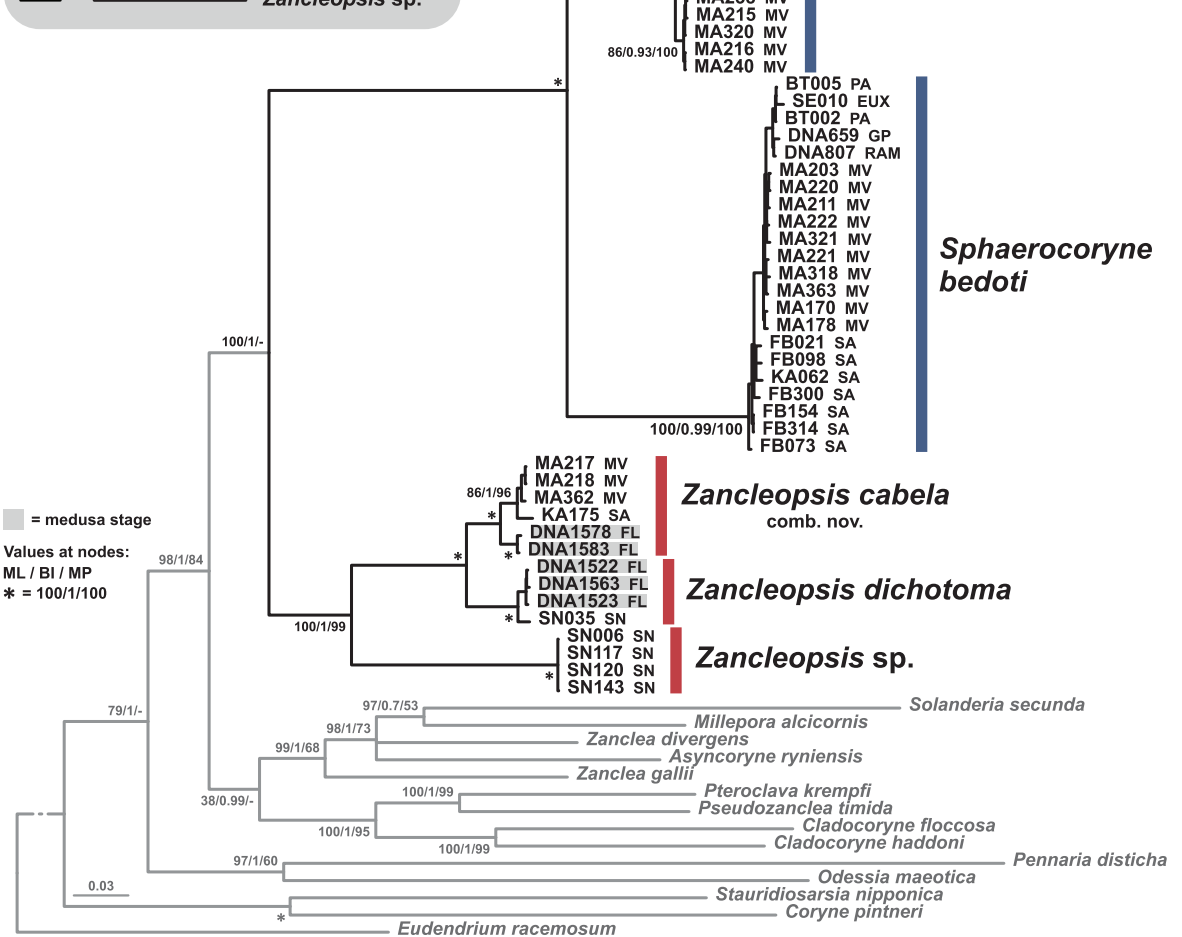

FIGURE 1 Phylogenetic hypotheses for the Sphaerocorynidae and Zancleopsidae. A) Sampling localities. B) Phylogenetic reconstruction of the Capitata based on the concatenated multi-locus dataset, with numbers at nodes representing ML bootstrap values, Bayesian posterior probabilities, and MP bootstrap values, respectively; asterisks denote maximal support for all analyses, whereas dashes denote absence of the node in the analysis; samples corresponding to medusa stages are highlighted in grey. C) Species tree of the Sphaerocorynidae and Zancleopsidae, with numbers at nodes representing Bayesian posterior probabilities. 
Astrocoryne-like polyps from Singapore and corresponding to the true $Z$. dichotoma, and a larger morph, herein linked to A. cabela polyps and corresponding to a different species. Our results demonstrate that the larger morph is indeed a different species, for which the combination Zancleopsis cabela comb. nov. is proposed (see 'Taxonomy' section). Genetic data also identified a third polyp-based Zancleopsis species from Singapore, Zancleopsis sp., as sister to a clade composed of $Z$. dichotoma and $Z$. cabela (figs. $1 \mathrm{~B}, \mathrm{C}$ ).

Species delimitations based on the $16 \mathrm{~S}$ rRNA consistently recovered ten species hypotheses (supplementary fig. S3), seven belonging to the Sphaerocorynidae and three to the Zancleopsidae, with no discordance among methods. Genetic distance analyses revealed limited intraspecific variation in the recovered species hypotheses (range: o-1.5\%), not overlapping with interspecific distances (range: 3.5-15.2 \%) (table 1). Notably, other sphaerocoynid sequences recovered from GenBank were included in the $16 \mathrm{~S}$ rRNA analyses, consisting of $S$. bedoti and $S$. agassizii examined in Nawrocki et al. (2010) and S. agassizii examined in Mendoza-Becerril et al. (2018). Species delimitation analyses found that these samples likely belong to two species not sampled in this study. Sequences from Nawrocki et al. (2010) from Florida and Panama proved to be almost identical, despite having been allocated to different nominal species, and were placed as the sister group of the Euphysilla clade (supplementary figs. $S_{1}$ and $S_{3}$ ). The identity of this species remains unknown and may represent another Euphysilla species. The sequence from Mendoza-Becerril et al. (2018) was obtained from polyps collected in the Gulf of Mexico, and was sister to the $H$. caribbensis clade, from which it showed a divergence of $3.5 \%$. Despite having been identified as $S$. agassizii, this colony showed a morphology similar to $H$. caribbensis (Mendoza-Becerril, personal communication) and may therefore represent another Heterocoryne species. Finally, the species hypothesis Euphysilla sp. was discriminated from E. pyramidata based exclusively on phylogenetic, species delimitation, and genetic distance results, since only a few EtOH-preserved Euphysilla sp. polyps were available and no morphological differences were detectable between the two species (see 'Taxonomy' section).

\section{Taxonomy}

Because most sphaerocorynid genera have hydroids that are practically inseparable from each other, a genus diagnosis based on morphology alone appears insufficient. Therefore, for each genus in the family Sphaerocorynidae a genetic diagnosis based on diagnostic molecular characters for 16S, COX1, COX3, 18S, and $28 \mathrm{~S}$ was provided. ITS was not included due to the large number of insertions or deletions. For details on the analysed material (e.g., DNA name, life stage, precise sampling locality and coordinates, GenBank accession numbers), see supplementary table $\mathrm{S}$.

\section{Class Hydrozoa Owen, 1843}

Order Anthoathecata Cornelius, 1992

Suborder Capitata Kühn, 1913

Family Sphaerocorynidae Prévot, 1959

Diagnosis: Colonies stolonal or erect; hydrocauli unbranched or sparingly branched, with terminal hydranths; perisarc thin, reaching hydranth; hydranth pyriform, with bulbous base and proboscis-like hypostome; no oral tentacles, but single, or partially fused capitate tentacles in whorls around broadest part of body; gonophores arising above or among tentacles as free medusae or fixed eumedusoids. Eumedusoid or free medusa with thick bell-shaped or conical umbrella; with or without apical projection, when present conical or dome-shaped, with broad apical chamber; manubrium 
TABLE 1 16S rRNA genetic distances (\% uncorrected $p$-distances) among and within Sphaerocorynidae and Zancleopsidae species

\section{Sphaerocorynidae}

\begin{tabular}{llllllll} 
E. pyramidata & $0.5 \pm 0.1$ & & & & & & \\
Euphysilla sp. & $4.8 \pm 0.9$ & $0.1 \pm 0.1$ & & & & & \\
? S. agassizii /S. bedoti* & $4.3 \pm 0.8$ & $5.1 \pm 0.9$ & $0.0 \pm 0.0$ & & & & \\
H. caribbensis & $9.6 \pm 1.2$ & $10.3 \pm 1.2$ & $9.3 \pm 1.1$ & $0.2 \pm 0.1$ & & & \\
? S. agassizii** & $7.8 \pm 1.0$ & $8.9 \pm 1.1$ & $7.8 \pm 1.0$ & $3.5 \pm 0.7$ & n.c. & & \\
K. diaphana & $7.1 \pm 1.0$ & $6.9 \pm 1.0$ & $6.8 \pm 1.0$ & $9.0 \pm 1.1$ & $7.8 \pm 1.1$ & $0.6 \pm 0.2$ & \\
S. bedoti & $9.6 \pm 1.2$ & $10.3 \pm 1.2$ & $9.2 \pm 1.2$ & $10.8 \pm 1.2$ & $11.6 \pm 1.2$ & $10.4 \pm 1.2$ & $1.0 \pm 0.2$ \\
\hline
\end{tabular}

Zancleopsidae

Z. cabela

$1.5 \pm 0.3$

Z. dichotoma

$5.8 \pm 0.8 \quad 1.2 \pm 0.3$

Zancleopsis sp.

$14.7 \pm 1.5 \quad 15.2 \pm 1.5 \quad 0.0 \pm 0.0$

Abbreviations and symbols: n.c. not calculated; *sequences from Nawrocki et al. (2010); ** sequence from Mendoza-Becerril et al. (2018).

flask-shaped, quadrate, or cruciform, mouth simple, round or cruciform; four tentacles, when present, with adaxial, evenly distributed, or spirally arranged nematocyst clusters, with a terminal, ellipsoid or spherical capitation; with or without abaxial ocelli; gonads adradial, confluent in perradii in mature specimens.

\section{Sphaerocoryne Pictet, 1893}

Diagnosis: Colonies stolonal; hydrocauli unbranched or sparingly branched, with terminal hydranths; perisarc reaching hydranth; hydranth pyriform, with bulbous base and proboscis-like hypostome; no oral tentacles, but capitate tentacles in whorls around broadest part of body; gonophores arising above tentacles and released as free medusae.

Adult medusa with thick ovoid to bellshaped umbrella; with or without apical projection, when present, conical or domeshaped, with broad apical chamber; manubrium flask-shaped, quadrate, or cruciform, mouth simple, round or cruciform; four tentacles, when present, with adaxial, evenly distributed, or spirally arranged nematocyst clusters, with a terminal, ellipsoid or spherical capitation; with abaxial ocelli; gonads adradial, confluent in perradii in mature specimens.

Genetic diagnosis: 79 molecular diagnostic characters differentiate Sphaerocoryne from other genera in the family, specifically 16 in the $16 \mathrm{~S}, 20$ in the Cox1, 22 in the $\operatorname{cox}_{3}, 10$ in the $18 \mathrm{~S}$, and 11 in the $28 \mathrm{~S}$ (table 2).

Remarks: The genus Sphaerocoryne comprises currently the following accepted nominal species: S. agassizii (McCrady, 1859), S. arcuata (Haeckel, 1879), S. bedoti Pictet, 1893, S. coccometra (Bigelow, 1909), and S. peterseni Bouillon, 1984. However, the genus shows some unresolved nomenclatural issues (Calder, 2010). Indeed, the type species $S$. agassizii was initially ascribed to the genus Corynitis McCrady, 1859, however this name is an invalid junior homonym of Corynitis Geyer, $183^{2}$ (Lepidoptera) and Corynitis Menge, 1854 (Araneae). Linvillea Mayer, 1910 was then proposed as a replacement name for Corynitis, and synonymised to Sphaerocoryne. However, Corynetes Haeckel, 1879 (an unjustified 
TABLE 2 Molecular diagnostic characters for each sphaerocorynid genus and molecular marker, except for ITS. Positions refer to reference sequences belonging to $S$. bedoti (MHNG-INVE-0137431), with the GenBank accession numbers MZ457614 (16S), MZ457396 (COX1), MZ463827 (CoX3), MZ457880 (18S), and MZ457801 (28S). When positions in the alignments differ from reference sequences they are also reported in parentheses. If a diagnostic position corresponds to a position in which there is a gap in the reference sequence, it is only reported in parentheses

\section{Genus / Nr. of Diagnostic position and relative nucleotide \\ molecular marker diagnostic positions}

\section{Sphaerocoryne}

$16 \mathrm{~S}$

COX1

$\operatorname{cox} 3$

18S

$28 \mathrm{~S}$

\section{Kudacoryne}

16S

COX1

$\operatorname{cox} 3$

$18 \mathrm{~S}$

$28 \mathrm{~S}$

\section{Euphysilla}

$16 \mathrm{~S}$

COX1

$\operatorname{cox} 3$

$18 \mathrm{~S}$

$28 \mathrm{~S}$

\section{Heterocoryne}

$16 \mathrm{~S}$
10

11

1

(1)

(1)

157: C, 174: G, 180: C, 209: A, 264: T, 269: A, 273: G, 287: T, 356:

$$
\text { C, 36o: A, 374: A, 376: C, 394: A, 396: T, 406: A, 408: G }
$$

27: T, 30: T, 72: A, 129: A, 138: T, 177: C, 186: T, 271: C, 273: T, 396: A, 402: A, 432: T, 466: A, 513: C, 528: T, 531: C, 570: T, 588 :

T, 591: C, 594: T

37: A, 55: C, 63: A, 109: G, 144: T, 145: A, 147: T, 150: G, 168:

G, 271: G, 336: A, 357: A, 401: C, 408: A, 418: G, 429: A, 477:

A, 480: T, 483: A, 563: G, 564: G, 573: G

(75): -, 175 (177): C, 185 (187): T, 186 (188): T, 1297 (1300): G, 1298 (1301): A, 1306 (1309): T, 1307 (1310): T, 1308 (1311): T, 1318 (1321): T

4: C, 32: T, 39: G, 43: C, 44: A, 45: T, 46: C, 93: T, 102: C, 103: T, 109: G

5०: A, 51: T, 52: A, 173: C, 186: T, 203: C, 216: C, 259: T, 285:

A, 290: T, 294: A, 380: C

30: C, 33: G, 75: A, 84: C, 180: G, 189: A, 261: C, 291: T, 348:

A, 381: C, 402: C, 411: A, 432: C, 483: T, 516: C, 564: G, 597: T

15: A, 36: G, 61: C, 99: T, 183: A, 216: C, 237: C, 271: T, 276:

A, 306: A, 345: T, 402: A, 417: T, 591: C

227 (230): A

439 (440): C

184: G, 275: G, 287: -, 36o: T, 434: G

168: T, 243: T, 274: C, 288: A, 289: G, 312: T, 339: T, 546: T, 6о3: T 79: G, 213: G, 255: T, 387: A

1420 (1423): T, 1476 (1479): A

53: C, 63: A, 116: C, 168: T, 178: G, 194: G, 208: C, 219: A, 276: G, 278: T, 280: A, 286: T, 298: G, 299: T, 331: C, 333: T, 344: T, 352: A, 354: T, 356: A, 379: C 
TABLE 2 Molecular diagnostic characters for each sphaerocorynid genus and molecular marker, except for ITS. Positions refer to reference sequences belonging to $S$. bedoti (MHNG-INVE-0137431), with the GenBank accession numbers MZ457614 (16S), MZ457396 (COX1), MZ463827 (CoX3), MZ45788o (18S), and MZ4578o1 (28S). When positions in the alignments differ from reference sequences they are also reported in parentheses. If a diagnostic position corresponds to a position in which there is a gap in the reference sequence, it is only reported in parentheses (Cont.)

$\begin{array}{ll}\text { Genus / } & \begin{array}{l}\text { Nr. of } \quad \text { Diagnostic position and relative nucleotide } \\ \text { molecular marker } \\ \text { diagnostic } \\ \text { positions }\end{array}\end{array}$

COX1

$\operatorname{cox} 3$

$18 \mathrm{~S}$

$28 \mathrm{~S}$
33

23

6

4
24: C, 64: A, 69: G, 94: C, 156: T, 186: T, 189: C, 204: T, 219: C, 234: C, 300: T, 366: G, 385: C, 393: C, 399: A, 438: C, 484: C, 498:

A, 514: A, 516: A, 537: C, 546: C, 585: C

6: T, 9: C, 14: C, 34: A, 36: A, 47: A, 58: T, 83: T, 99: G, 102: G, 120:

G, 145: C, 162: T, 216: A, 237: T, 250: G, 294: A, 319: A, 320: T, 342:

C, 351: A, 355: A, 356: G, 370: A, 372: A, 375: A, 387: G, 406:

T, 430: A, 438: C, 504: A, 562: A, 588: G

177 (179): T, (226): A, 224 (227): A, 227 (230): T, 727 (730):

T, 1645 (1648): G

158: T, 16o: T, (186): T, 262 (263): A emendation of Corynitis) is an available name with priority over Linvillea and Sphaerocoryne. Therefore, if $S$. bedoti and $S$. agassizii are not congeneric, the latter should be transferred to the genus Corynetes and Sphaerocoryne will remain valid at least for $S$. bedoti. On the other hand, if the two species are demonstrated to be congeneric, the widely used generic name Sphaerocoryne will not be valid anymore, and a case should be submitted to the International Commission on Zoological Nomenclature (ICZN) to assess the merits of its conservation.

\section{Sphaerocoryne bedoti Pictet, 1893}

Sphaerocoryne bedoti Pictet, 1893: 10, pl. 1 figs. 5-6; Millard, 1975: 54, fig. 2oe; Wedler \& Larson, 1986: 8o, fig. 3Ca-b; Hirohito, 1988: 37, fig. 11d; Galea, 2008: 13, fig. 3f; Schuchert, 2010: 467, fig. 10a-f; Nagale \& Apte, 2014: 1, fig. 2a-d. Clavatella multitentaculata Warren, 1908: 278, pl. XLV figs. 7-9.

Syncoryne flexibilis Fraser, 1938: 15, pl. II fig. 8. Sphaerocoryne multitentaculata. Yamada \& Konno, 1973: 104, figs. 1-3.
Sphaerocoryne cf. agassizii. Miglietta et al. 2018: 106, suppl. data, p. 27.

Examined material: Sample BToo7, Panama, August 2015, polyps in ethanol. - Sample BTo3o Panama, August 2015, polyps in ethanol. - Sample FB 021, Saudi Arabia, 01/05/2017, polyps in ethanol and formalin. - Sample FB073, Saudi Arabia, 02/05/2017, polyps in ethanol and formalin. - Sample FBo98, Saudi Arabia, 02/05/2017, polyps in ethanol. Sample FB154, Saudi Arabia, 03/05/2017, polyps in ethanol. - Sample F B300, Saudi Arabia, 05/05/2017, polyps in ethanol and formalin. - Sample FB314, 05/05/2017, polyps in ethanol and formalin. - Sample KAo62, Saudi Arabia, 15/12/2015, polyps in ethanol. - Sample mh201, Maldives, January 2015, polyps in ethanol and formalin. - Sample spoo3, Maldives, April 2015, polyps in ethanol. - Sample MA16oo2, Maldives, 19/01/2016, polyps in ethanol and formalin. -Sample MA16o31, Maldives, 27/01/2016, polyps in ethanol. - Sample MA16o56, Maldives, og/O2/2016, polyps in 
ethanol and formalin. - Sample MA16057, Maldives, 09/02/2016, polyps in ethanol and formalin. - Sample MA16o58, Maldives, o9/o2/2016, polyps in ethanol and formalin. - Sample MA1016o20, Maldives, 14/10/2016, polyps in ethanol and formalin. - Sample MA0117107, Maldives, 09/02/2017, polyps in ethanol and formalin. - Sample MA0117118, Maldives, 09/02/2017, polyps in ethanol and formalin (MHNG-INVE-O137431). - Sample STE025, Sint Eustatius, 14/06/2015, polyps in ethanol. - Sample MHNG-INVE-oo6o977, Guadeloupe, 23/03/2008, polyps in ethanol. -Sample MHNG-INVE-0071921, June 2010, Madeira, polyps in ethanol.

Description: Polyp. Colonies monomorphic, living in association with sponges and occasionally with encrusting algae (figs. 2AB). Hydrorhiza tubular, branched, covered by perisarc and growing within the sponge host. Pedicels long (up to $4 \mathrm{~mm}$ ), unbranched, covered by a slightly wrinkled, thin perisarc (fig. 2A) and occasionally covered by debris (fig. $2 \mathrm{~B}$ ). Hydranth pyriform, up to $2 \mathrm{~mm}$ long, with variable diameter $(130-510 \mu \mathrm{m})$ (figs. 2A-E). Hypostome proboscis-like, contractile, with a band of nematocysts below the mouth (fig. $2 \mathrm{~F}$ ), with a highly extensible mouth (fig. $2 \mathrm{G}$ ). Up to 40 tentacles with no evident arrangement and closely scattered in the broadest part of the hydranth (figs. $2 \mathrm{D}$, E). Each tentacle with a terminal, nematocyst-rich capitulum (diameter: $110-140 \mu \mathrm{m}$ in the distal whorls; $70-85 \mu \mathrm{m}$ in the proximal whorls), with a central inclusion (fig. $2 \mathrm{H}$ ). Tentacles up to $1 \mathrm{~mm}$ long in the distal whorls and shorter in the proximal whorl. Up to six clusters of $5^{-20}$ medusa buds at the same stage of maturation developing above distal tentacles (figs. $2 \mathrm{C}, \mathrm{I}$ ), marked by a red pigmented band (fig. $2 \mathrm{E}, \mathrm{J}$ ). In some instances, tentacles disappear in polyps bearing medusa buds (reproductive exhaustion) (fig. $2 \mathrm{~K}$ ). Living hydranths with white, or yellowish hypostome, a regular bright red band below the hypostome, gastric cavity transparent or yellowish in the broadest part and whitish below the broadest part of polyps (figs. 2AE). Desmonemes (fig. $2 \mathrm{M}$ ), small stenoteles (fig. $2 \mathrm{M}$ ) and large stenoteles (fig. $2 \mathrm{~N}$ ) occurring simultaneously and concentrated in the capitula, and rarely scattered in the hydrorhiza and in the hydranth; heteronemes (fig. $2 \mathrm{O}$ ) in the hydrocaulus and hydrorhiza; small stenoteles in a band around the hypostome.

Newly liberated medusa. Small, 105-170 $\mu \mathrm{m}$ wide and 110-200 $\mu \mathrm{m}$ high, with nematocysts scattered on the exumbrella (fig. $2 \mathrm{~L}$ ). Manubrium short, 40-50 $\mu \mathrm{m}$ long and 80-110 wide at the base, with a circular mouth. No radial canals visible, and four small triangular bulbs. When released, medusae with no tentacles; six days after release, medusae of the same size, with four short tentacles, $40-50 \mu \mathrm{m}$ long. Living medusae transparent with reddish bulbs. Desmonemes and small stenoteles scattered on the exumbrella.

Polyp and newly liberated medusa cnidome. i) Desmonemes (undischarged: 10-12 $\times 5^{-6}$ $\mu \mathrm{m}$; discharged capsule: $\left.10-11 \times 5^{-6} \mu \mathrm{m}\right)$. ii) Heteronemes (undischarged: $20-22 \times 8-10$ $\mu \mathrm{m})$. iii) Large stenoteles (undischarged: $25^{-28} \times 18-20 \mu \mathrm{m}$; discharged capsule: $20-21$ $\times$ 14-16 $\mu \mathrm{m}$ ). iv) Small stenoteles (undischarged: 10-12 × 8-10 $\mu \mathrm{m}$; discharged capsule: $10 \times 6 \mu \mathrm{m})$.

Distribution: Atlantic Ocean and Caribbean Sea (Madeira; Guadeloupe, Panama, Puerto Rico, Sint Eustatius), Red Sea and IndoWest Pacific (Saudi Arabia; India, Indonesia, Maldives, South Africa), and East Pacific (Colombia, Ecuador, Mexico, Panama, Japan).

Remarks:This species was initially described by Pictet (1893) based on polyp stage alone. The most striking difference to other sphaerocorynid species is the typical colouration of the polyp and the medusa buds forming large clusters, as already noted by Warren (1908). According to previous descriptions, polyps of

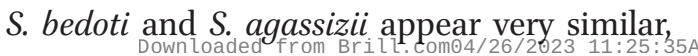


the latter nevertheless not being thoroughly characterised in the original description by McCrady (1859). A possible difference between S. agassizii and other sphaerocorynid species is the presence of two opposite tentacles in medusa buds and newly released medusae, as described for instance in Pictet (1893), Hargitt (1904), and Calder (1971), something never observed in the species investigated herein. Medusa buds and newly released medusae in $S$. bedoti are small in size and with no developed tentacles or ocelli, as depicted by Yamada \& Konno (1973) and in the present work. Most of the differences between $S$. bedoti and $S$. agassizii occur in the adult medusa, specifically in the exumbrellar nematocyst rows and in the tentacular nematocyst clusters (Schuchert, 2010). However, adult medusae clearly ascribable to $S$. bedoti and S. agassizii could not be collected for the present work, and, therefore, the status of the two species and the consequent taxonomic implications related to the validity of the genera Sphaerocoryne and Corynetes must remain unresolved. The paucity of reliable diagnostic characters in the polyp stage of sphaerocorynid species has led to subsequent confusion in species identifications in the family, and many records should be considered dubious due to the lack of thorough descriptions, drawings and photos of colonies, or genetic data. Therefore, we abstain from including these records as synonyms.

\section{Kudacoryne Maggioni gen. nov.}

http://zoobank.org/urn:lsid:zoobank.org:act: 8BF43568-3611-402F-A24D-C54Bo6oAA119

Diagnosis: Hydroids like in Sphaerocoryne; medusae unknown.

Genetic diagnosis: 45 molecular diagnostic characters differentiate Kudacoryne from other genera in the family, specifically 12 in the $16 \mathrm{~S}, 17$ in the COx1, 14 in the COx 3,1 in the $18 \mathrm{~S}$, and 1 in the $28 \mathrm{~S}$ (table 2 ).
Etymology: The generic name derives from the combination of 'Kuda', meaning 'little' in Divehi (Maldivian) language, reflecting the smaller size of polyps compared to other sphaerocorynid species, and -coryne.

Type species: Kudacoryne diaphana Maggioni sp. nov.

\section{Kudacoryne diaphana Maggioni sp. nov.}

http://zoobank.org/urn:lsid:zoobank.org:act: 741D2566-6F92-408B-AE3A-261A7A6F19E9

Type Material: Holotype - Sample KAO79, Saudi Arabia, 16/12/2015, polyps in formalin and ethanol (MHNG-INVE-O137429). Paratype - Sample MAo117113, Maldives, o9/o2/2017, polyps in formalin and ethanol (MHNG-INVE-0137428).

Examined material: Sample FBo11, Saudi Arabia, 30/04/2017, polyps in ethanol and formalin. - Sample FBo56, Saudi Arabia, o1/05/2017, polyps in ethanol and formalin. - Sample FB138, Saudi Arabia, o3/05/2017, polyps in ethanol and formalin. - Sample FB143, 03/05/2017, polyps in ethanol and formalin. Sample FB19o, 04/05/2017, polyps in ethanol and formalin. - Sample KAo83, Saudi Arabia, 16/12/2015, polyps in ethanol and formalin. Sample KAo88, Saudi Arabia, 16/12/2015, polyps in ethanol and formalin. - Sample KAo89, Saudi Arabia, 16/12/2015, polyps in ethanol. - Sample KAo9o, Saudi Arabia, 16/12/2015, polyps in ethanol. - Sample KAo93, Saudi Arabia, 16/12/2015, polyps in ethanol and formalin. - Sample KA114, Saudi Arabia, 14/12/2015, polyps in ethanol and formalin. - Sample KA129, Saudi Arabia, $15 / 12 / 2015$, polyps in ethanol and formalin. - Sample KA173, Saudi Arabia, 17/12/2015, polyps in ethanol. - Sample KA177, Saudi Arabia, 17/12/2015, polyps in ethanol. - Sample KA18o, Saudi Arabia, 17/12/2015, polyps in ethanol. - Sample MA16o21, Maldives, 25/01/2016, polyps in ethanol. - Sample MA16050, Maldives, o8/o2/2016, polyps in ethanol and formalin. 

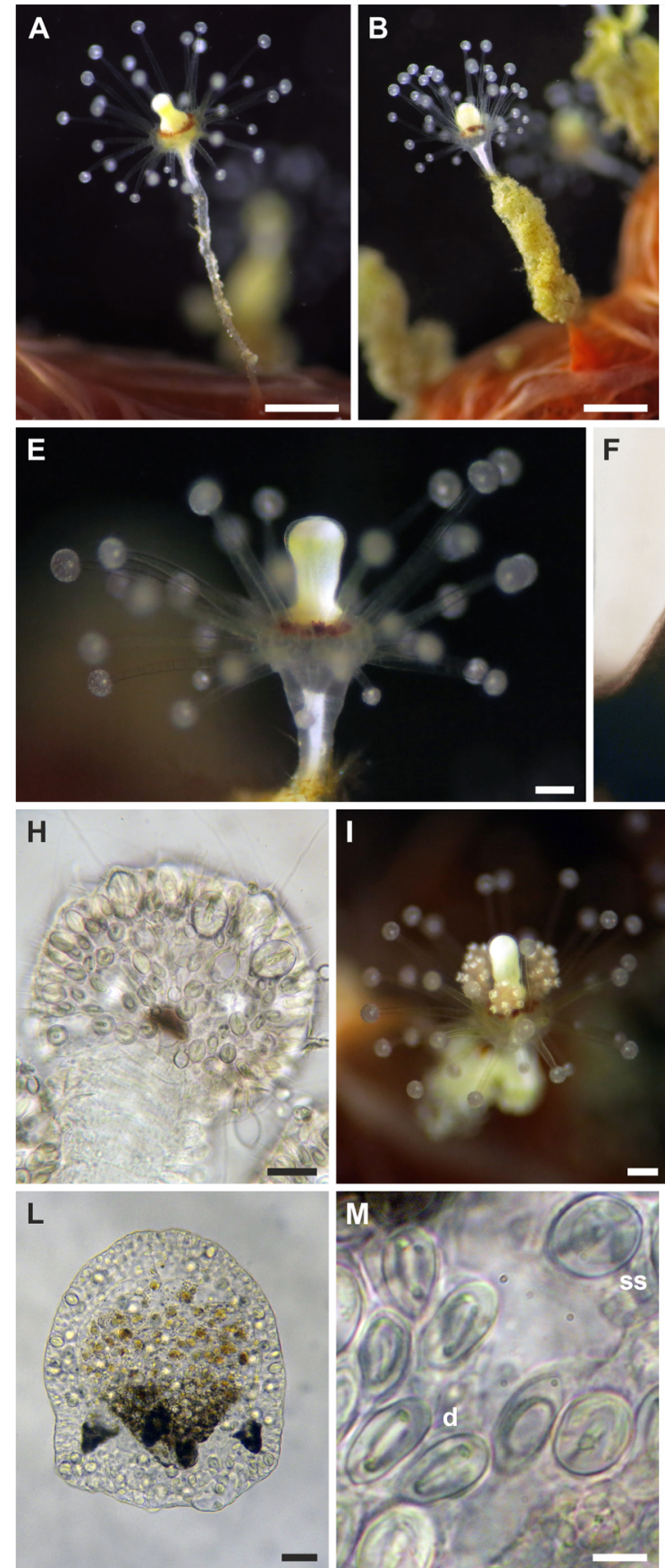
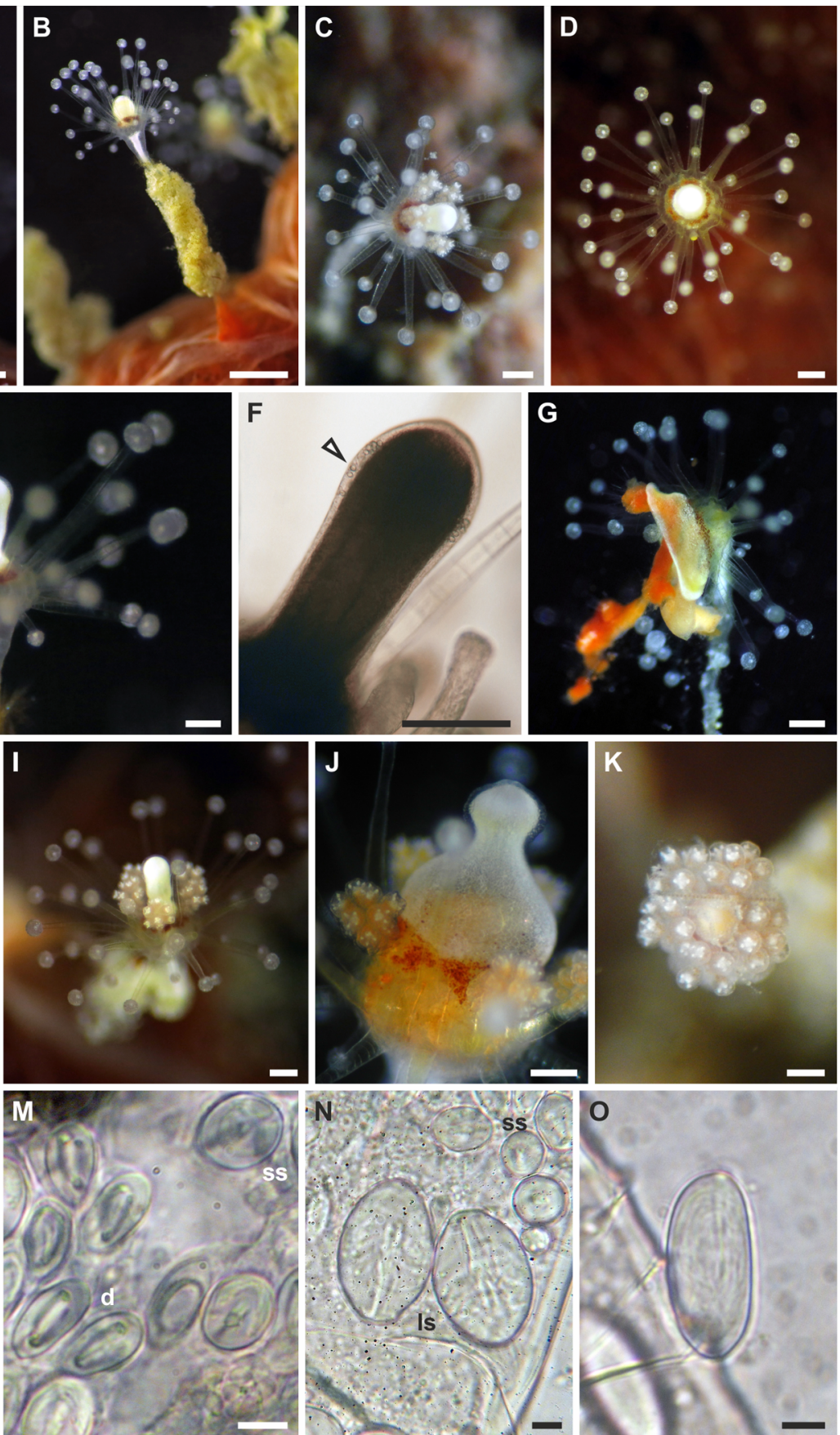

FIGURE 2 Sphaerocoryne bedoti. Polyps from A, B) Maldives and C) Sint Eustatius. D) Tentacles organisation. E) Close-up of a hydranth showing the typical colouration. F) Hypostome, with a nematocyst band (arrowhead). G) Living polyp detached from the host and trying to ingest a portion of the host sponge. H) Capitulum with a central inclusion. I) Polyp with medusa buds organised in clusters. J) Close-up of a polyps with medusa buds clusters arising from the red band area. K) Polyp with medusa buds showing reproductive exhaustion. L) Newly released medusa. M) Desmonemes (d) and small stenoteles (ss) from the polyp. N) Large stenoteles (ls) and small stenoteles (ss) from the polyp. O) Heteroneme from the polyp. Scale bars: A, B) $0.5 \mathrm{~mm}$; C-G, I-K) $0.2 \mathrm{~mm}$; H, L) $25 \mu \mathrm{m}$; M-O) $5 \mu \mathrm{m}$. 
- Sample MA16o51, Maldives, o8/o2/2016, polyps in ethanol and formalin. - Sample MA16o64, Maldives, 31/03/2016, polyps in ethanol. - S ample MAO416125, Maldives, 17/04/2016, polyps in ethanol and formalin.

Description: Polyp. Colonies monomorphic (fig. 3A), living in symbiosis with sponges, and occasionally sharing the host with other hydrozoan species (e.g., Zancleopsis cabela in the Maldives). Hydrorhiza tubular, branched, covered by thin perisarc, extending within the sponge host. Pedicels short (up to $180 \mu \mathrm{m}$ ), unbranched, covered by a thin perisarc, often overgrown by the sponge. Hydranth pyriform, up to $0.7 \mathrm{~mm}$ long, with variable diameter (50-23o $\mu \mathrm{m})$ (figs. 3A-D). Hypostome proboscis-like, contractile (fig. $3 \mathrm{E}$ ). Up to 22 tentacles arranged irregularly in 2-3 close whorls in the broadest part of the polyp, with the distal whorl directed upward (figs. 3A-D). Tentacles 100-300 $\mu \mathrm{m}$ long. Each tentacle with a terminal, nematocyst-rich capitation (diameter: 70-100 $\mu \mathrm{m}$ ) (fig. 3F). Up to two medusa buds at different stages of maturation develop above tentacles, singly on blastostyles (fig. $3 \mathrm{G}$ ). Living hydranths transparent, with white mouths (figs. 3A-D). Desmonemes, small and large stenoteles (fig. 3I) occurring in the capitula, as well as scattered in the hydrorhiza; macrobasic mastigophores (fig. 3J) occurring in the pedicel and hydrorhiza.

Newly liberated medusa. Bell-shaped umbrella, 370-410 $\mu \mathrm{m}$ wide and 405-420 $\mu \mathrm{m}$ high, with several nematocysts scattered on the exumbrella (fig. $3 \mathrm{H}$ ). Manubrium cylindrical, about $300 \mu \mathrm{m}$ long, $2 / 3$ to $3 / 4$ of the bell height, distally provided with a circular mouth. Four radial canals ending in four bulbs with a diameter of 70-80 $\mu \mathrm{m}$, containing nematocysts. When released, medusae with no tentacles and no ocelli. Living medusae transparent with reddish manubrium. Microbasic mastigophores and small stenoteles scattered on the exumbrella and large stenoteles in bulbs.
Polyp and newly released medusa cnidome. i) Desmonemes (undischarged: 9-10 $\times 4-5 \mu \mathrm{m}$; discharged capsule: $6 \times 4 \mu \mathrm{m})$. ii) Macrobasic mastigophores (undischarged: $10-11 \times 5^{-6 \mu \mathrm{m}}$; discharged capsule: $8-9 \times 5 \mu \mathrm{m}$; shaft: $45^{-55}$ $\mu \mathrm{m})$. iii) Microbasic mastigophores (undischarged: $8 \times 4-5 \mu \mathrm{m}$; discharged capsule: 7 $\times 4 \mu \mathrm{m}$; shaft: $\left.5^{-8} \mu \mathrm{m}\right)$. iv) Large stenoteles (undischarged: $18-20 \times 12-14 \mu \mathrm{m}$; discharged shaft: $16-17 \times 11 \mu \mathrm{m})$. v) Small stenoteles (undischarged: $10-13 \times 7-10 \mu \mathrm{m}$; discharged capsule: $\left.7-11 \times 5^{-8} \mu \mathrm{m}\right)$.

Etymology: The species name derives from Greek diaphanes, referring to the absence of a typical colouration of polyps, being almost completely transparent.

Distribution: Red Sea and Indo-West Pacific (Saudi Arabia; Maldives).

Remarks: The polyps of this species largely agree with the description of other sphaerocorynid polyps. The main differences to other species rely on the colour and size of polyps, being transparent, smaller, and with shorter pedicels in Kudacoryne diaphana. Additional differences are in medusa buds, being in this species up to two in number, not in clusters, and giving rise to free-swimming medusae. Given these differences, and the divergent position in the proposed phylogenetic hypotheses, the new genus Kudacoryne was established (authored by Maggioni). However, we admit that the morphological differences are minimal and likely not useful to distinguish the genera in practice. Therefore, we resorted to a more objective genetic diagnosis.

Since the adult medusa of Kudacoryne diaphana is currently unknown, it is possible that this species will later be synonymised with a Sphaerocoryne or Euphysilla species with a name that is based on the medusa stage, but for which no genetic data are available yet.

\section{Euphysilla Kramp, 1955}

Diagnosis: Hydroids like in Sphaerocoryne. 

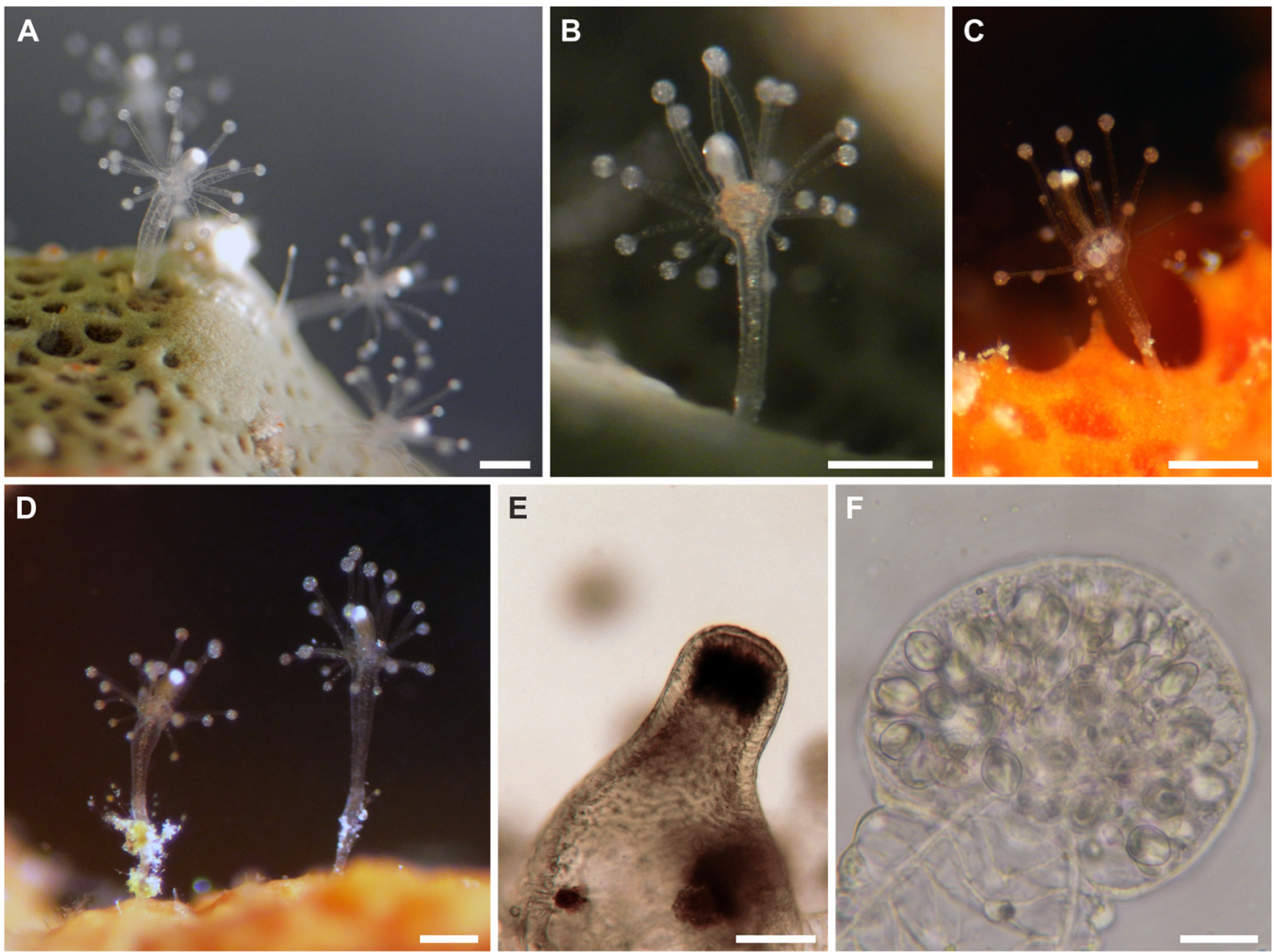

F
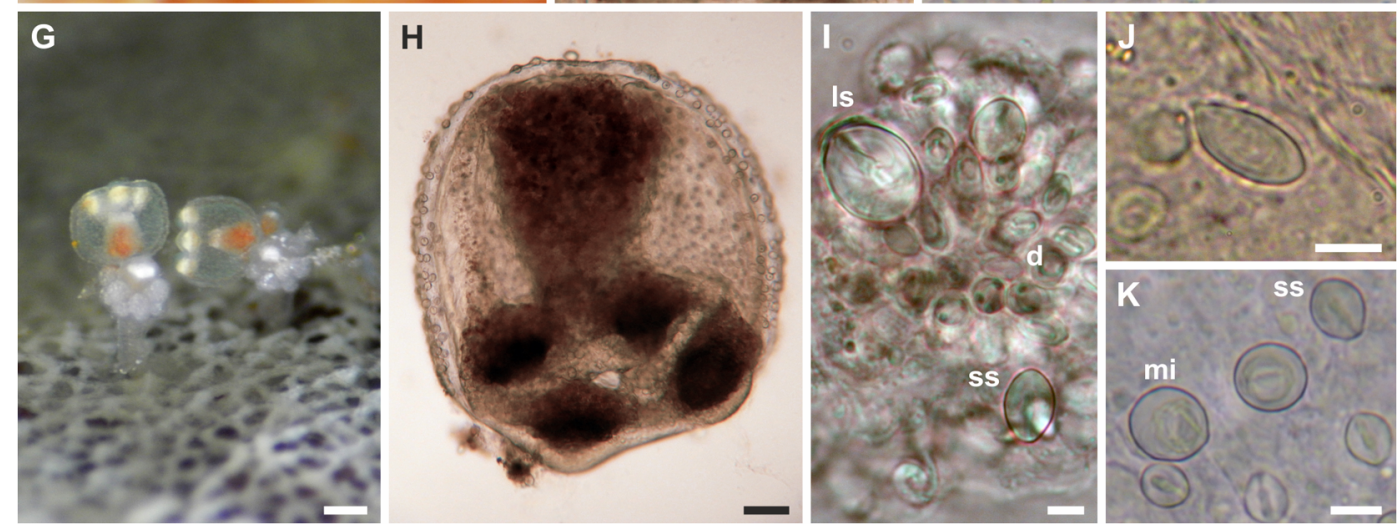

FIGURE 3 Kudacoryne diaphana. Polyps from A, B) Red Sea and C, D) Maldives. E) Hypostome. F) Capitulum. G) Polyps with medusa buds a few hours before release. H) Newly released medusa. I) Large stenoteles (ls), small stenoteles (ss), and desmonemes (d) from the polyp stage. J) Macrobasic mastigophore from the polyp stage. K) Small stenoteles (ss) and microbasic mastigophores (mi) from the newly released medusa. Scale bars: A-D, G) $0.2 \mathrm{~mm}$; E, H) $50 \mu \mathrm{m}$; F) $20 \mu \mathrm{m}$; I-K) $5 \mu \mathrm{m}$.

Medusa umbrella ovoid, with apical chamber; manubrium with quadratic base; mouth circular; no gastric peduncle; mature gonads surrounding the whole manubrium; four equally developed tentacles with adaxial or abaxial nematocyst clasps and a terminal cluster; ocelli absent or underdeveloped and very inconspicuous. Medusa buds on manubrium usually present.

Genetic diagnosis: 20 molecular diagnostic characters differentiate Euphysilla from other genera in the family, specifically, 5 in the $16 \mathrm{~S}$, 
9 in the Cox1, 4 in the $\operatorname{cox}_{3}$, and 2 in the $18 \mathrm{~S}$ (table 2).

Remarks: Euphysilla is very similar to Sphaerocoryne, differing only in the medusa stage by the absence or reduction of the ocelli and the frequent presence of medusa buds. Although ocelli have not been reported in Euphysilla, we noted in some of the specimens of $E$. pyramidata faint orange-yellow spots on the abaxial side of the tentacle bulbs, just at the position where normally ocelli would occur (fig. 4M). The spots are very inconspicuous and easily overlooked as they have the same colour as the other pigmented tissues of the medusa. It is unclear if these spots are functional ocelli. These spots were apparently overlooked by Schuchert \& Collins (2021). The genus comprises currently the following species: Euphysilla peterseni Allwein, 1967, E. pyramidata Kramp, 1955, and Euphysilla tubularia Huang, Xu \& Lin, 2015. The latter species appears indistinguishable from E. pyramidata (Schuchert \& Collins, 2021).

\section{Euphysilla pyramidata Kramp, 1955}

Euphysilla pyramidata Kramp, 1955: 245, pl. 1 fig. 1, pl. 2 fig. 3; Kramp, 1965: 4; Vannucci \& Santhakumari, 1969: 40; Schmidt, 1973: 16; Hamond, 1974: 554, figs 4-6; Segura-Puertas, 1984: pl. 2 fig. 2; Buecher \& Gibbons, 2000: 127; $\mathrm{Xu}$ \& Huang, 2004: 56o, fig. 9; Schuchert \& Collins, 2021: 265, fig. 17.

Sphaerocoryne sp. Di Camillo et al. 2008: 1591; Maggioni et al. 2017: 737 .

Examined material: Sample spoo2, Maldives, April 2015, polyps in ethanol. - Sample MA16oo1, Maldives, 19/01/2016, polyps in ethanol and formalin. - Sample MA16007, Maldives, 21/01/2016, polyps in ethanol. Sample MA16o14, Maldives, 22/01/2016, polyps in ethanol and formalin. - Sample MA16o22, Maldives, 25/01/2016, polyps in ethanol and formalin. - Sample MA16o39, Maldives, 29/01/2016, polyps in ethanol. -
Sample MA16054, Maldives, o9/02/2016, polyps in ethanol and formalin. - Sample MA0117032, Maldives, 31/01/2017, polyps in ethanol. - Sample MAo117133, Maldives, 13/02/2017, polyps in ethanol and formalin (MHNG-INVE-0137430). - Sample STE04O, Sint Eustatius, 18/06/2015, polyps in ethanol.Sample BFLA4396, off Florida, 17/05/2020, medusa in ethanol and in situ photos. Sample BFLA4397, off Florida, 17/05/2020, medusa in ethanol and in situ photos. Sample BFLA4478, off Florida, 18/o6/2020, medusa in ethanol and in situ photos.

Description: Polyp. Colonies monomorphic, living in association with sponges and occasionally growing on carbonatic rock (fig. 4A-C). Hydrorhiza tubular, branched, covered by perisarc and growing in the sponge host. Pedicels long (up to $5 \mathrm{~mm}$ ), unbranched, covered by a smooth, thin perisarc (fig. 4A), occasionally highly covered by debris (fig. 4C). Hydranth pyriform, up to $2.5 \mathrm{~mm}$ long, with variable diameter $(150-420 \mu \mathrm{m})$ (figs. $4 \mathrm{~A}-\mathrm{D})$, in some cases directed at an angle of $90^{\circ}$ to the pedicel (figs. $4 \mathrm{~B}, \mathrm{C}$ ). Hypostome proboscis-like, contractile, with a band of nematocysts below the mouth (fig. $4 \mathrm{E}$ ). Up to 45 tentacles arranged in $3^{-5}$ close whorls in the broadest part of the polyp, and grouped longitudinally (fig. $4 \mathrm{~F}$ ). Each tentacle with a terminal, nematocyst-rich capitulum (diameter: 100-140 $\mu \mathrm{m}$ in the distal whorls; $85-95 \mu \mathrm{m}$ in the proximal whorl). Tentacles up to $600 \mu \mathrm{m}$ long in the distal whorls, shorter in the proximal whorl. Up to seven medusa buds at the same stage of maturation develop above distal tentacles, singly on blastostyles (fig. $4 \mathrm{G})$. Living hydranths with white mouths, an irregular yellow-orange band below the hypostome, at the level of the gastric cavity, and white, clearly visible, mesenteries (figs. 4A-D). Small and large stenoteles (fig. $4 \mathrm{H}$ ) and desmonemes (fig. 4I) occurring simultaneously and concentrated in the capitula, and rarely also scattered in the hydrorhiza and in 

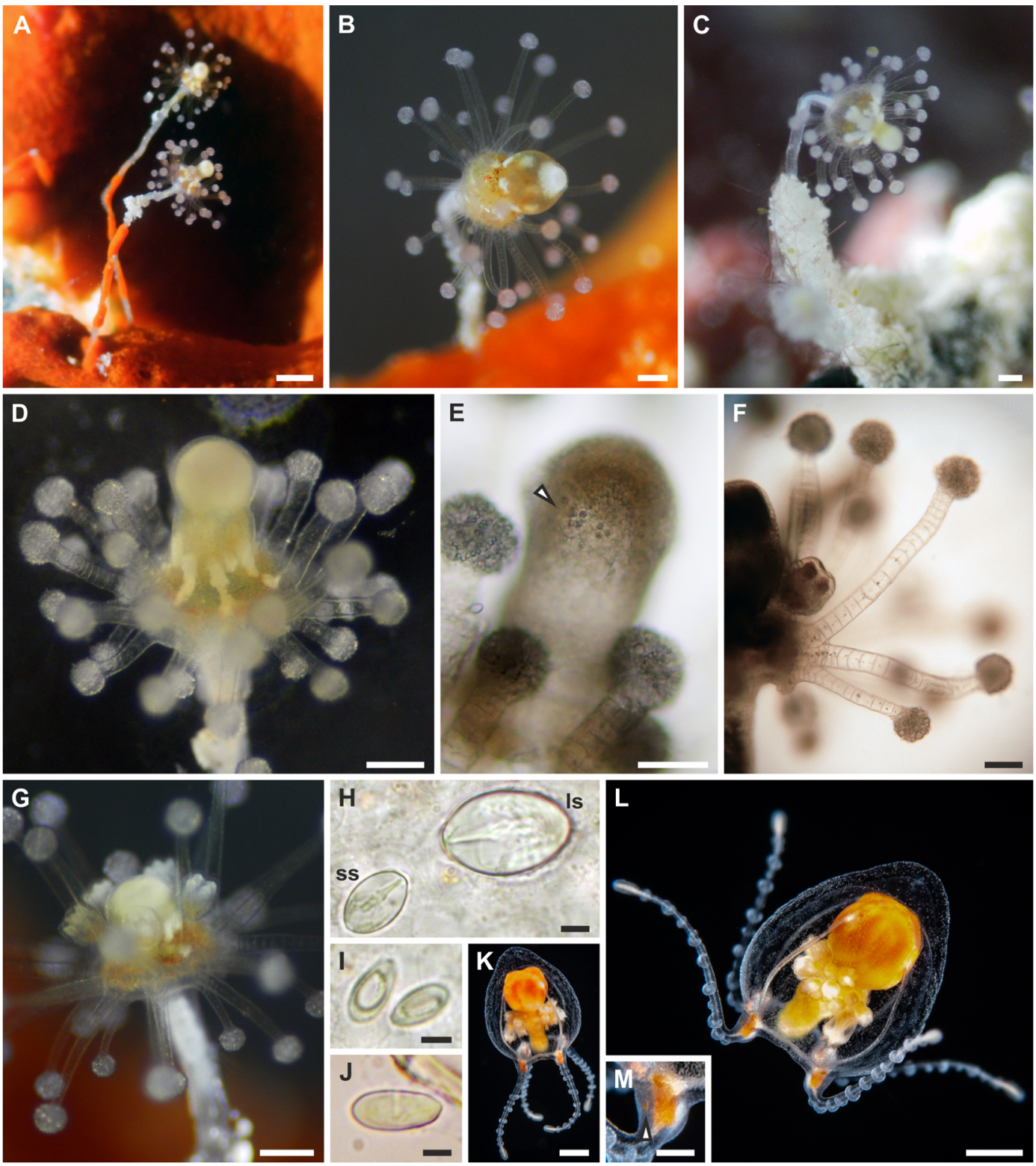

FIgure 4 Euphysilla pyramidata. A, B, C) Polyps from the Maldives. D) Close-up of a hydranth showing the typical colouration. E) Hypostome with nematocysts (arrowhead). F) Longitudinal organisation of tentacles. G) Polyps with medusa buds. H) Large stenoteles (ls), small stenoteles (ss), I) desmonemes, and J) heteronemes from the polyp. K, L) Medusae with medusa buds. M) Detail of a bulb showing a reduced abaxial ocellum (arrowhead). Scale bars: A) o.5 mm; B-D, G) $0.2 \mathrm{~mm}$; E, F) o.1 mm; H-J) $5 \mu \mathrm{m}$; $\mathrm{K}, \mathrm{L}) \sim 1 \mathrm{~mm} ; \mathrm{M}) \sim 0.3 \mathrm{~mm}$.

the hydranth; heteronemes rarely found in the hydrocaulus (fig. $4 \mathrm{~J}$ ); small stenoteles in a band around the hypostome.

Polyp cnidome. i) Desmonemes (undischarged: $10 \times 4-5 \mu \mathrm{m}$; discharged capsule:
$8 \times 5 \mu \mathrm{m})$. ii) Heteronemes (undischarged: 16 $\times 7$ ). iii) Large stenoteles (undischarged: $22-24$ $\times 12-15 \mu \mathrm{m}$; discharged capsule: $19-21 \times 12-13$ $\mu \mathrm{m})$. iv) Small stenoteles (undischarged: 11-14 $\times 8-10 \mu \mathrm{m}$; discharged capsule: $10 \times 7-8 \mu \mathrm{m})$. 
Adult medusa (from Schuchert \& Collins, 2021). Umbrella $2-4 \mathrm{~mm}$ in height, oviform, with apical thickening of very variable height, lateral walls thin, exumbrella with scattered nematocysts (fig. $4 \mathrm{~K}, \mathrm{~L}$ ). Above manubrium an apical chamber, without apparent connection to gastric cavity, size variable depending on size of apical process. Manubrium an inverted cone, as long as bell cavity, base broad and cruciform in life, more square-shaped when preserved, upper part of manubrium cylindrical, narrowing to tubular lower part of manubrium ending in small, circular mouth. All observed medusae were budding medusae, buds in groups on all four perradial sides of the manubrium in about the middle of the manubrium. Gonad-like opaque tissue layer covers manubrium above buds. Colour of manubrium intensively yellow-orange. Radial canals connected to manubrium by apparent short mesenteries (giving cruciform manubrium base), thin; circular canal more rectangular than circular. Four tentacles, contracted about half the length of the bell height, each with 8-12 crescent-shaped, clasping nematocyst pads, all in one row on adaxial side, terminal button ovoid, as wide as rest of tentacle. Four tentacle bulbs relatively small, orange-yellow, with inconspicuous orange-yellow dots on abaxial side of tentacle bulbs resembling reduced ocelli (fig $4 \mathrm{M}$ ).

Adult medusa cnidome (preserved material). i) Desmonemes $(4 \times 9 \mu \mathrm{m})$. ii) Small stenoteles $(7 \times 10 \mu \mathrm{m})$. iii) Large stenoteles $(12 \times 13$ $\mu \mathrm{m})$. iv) Spherical microbasic euryteles with barbed filament, shaft appears without barbs $(7 \times 10 \mu \mathrm{m})$.

Distribution: Atlantic Ocean and Caribbean Sea (Benin, Florida; Sint Eustatius), Red Sea and Indo-West Pacific (Northern Red Sea; Australia, India, Indonesia, Madagascar, Maldives, South Africa, Taiwan Strait), and East Pacific. The records from Papua
New Guinea may refer to another species (Schuchert \& Collins, 2021).

Remarks: The polyp stage of E. pyramidata is herein described for the first time, and largely resembles Sphaerocoryne and Kudacoryne polyps. However, differences are found in the colouration of the hydranth, tentacle organisation, lack of inclusions in the capitula, and organisation and number of medusa buds. It is possible that polyps of this species were assigned to the genus Sphaerocoryne in previous works, as for instance Sphaerocoryne sp. from Indonesia by Di Camillo et al. (2008) (CG Di Camillo, pers. comm.). The medusa shows strong similarities to Sphaerocoryne medusae as well, but is distinguished by the absence or reduction of ocelli and the common presence of medusa buds on the manubrium. Schuchert \& Collins (2021) initially detected the genetic similarities in the $16 \mathrm{~S}$ rRNA region between a Sphaerocoryne polyp from Maldives (Maggioni et al., 2017) and $E$. pyramidata medusae from Florida, here confirmed on the basis of multiple DNA regions and phylogenetic analyses. They also suggested that E. pyramidata in the sense of Bouillon (1978) may be a species complex due to morphological differences, but further sampling is still needed to address this issue.

\section{Euphysilla sp.}

Sphaerocoryne cf. agassizii. Miglietta et al. 2018: 105, suppl. data, p. 27.

Examined material: Sample BTo12, Panama, August 2015, polyps in ethanol. -BT015, Panama, August 2015, polyps in ethanol. Sample AL04, Martinique, 30/o1/2014, polyps in ethanol (MHNG-INVE-0137432).

Description: Polyp. Colonies monomorphic, living in association with sponges. Pedicels long (up to $8 \mathrm{~mm}$ ), unbranched, covered by a smooth, thin perisarc (fig. $5 \mathrm{~A}$ ). Hydranth pyriform, up to $0.3 \mathrm{~mm}$ long when contracted, with a proboscis-like hypostome (fig. 5B). Up 

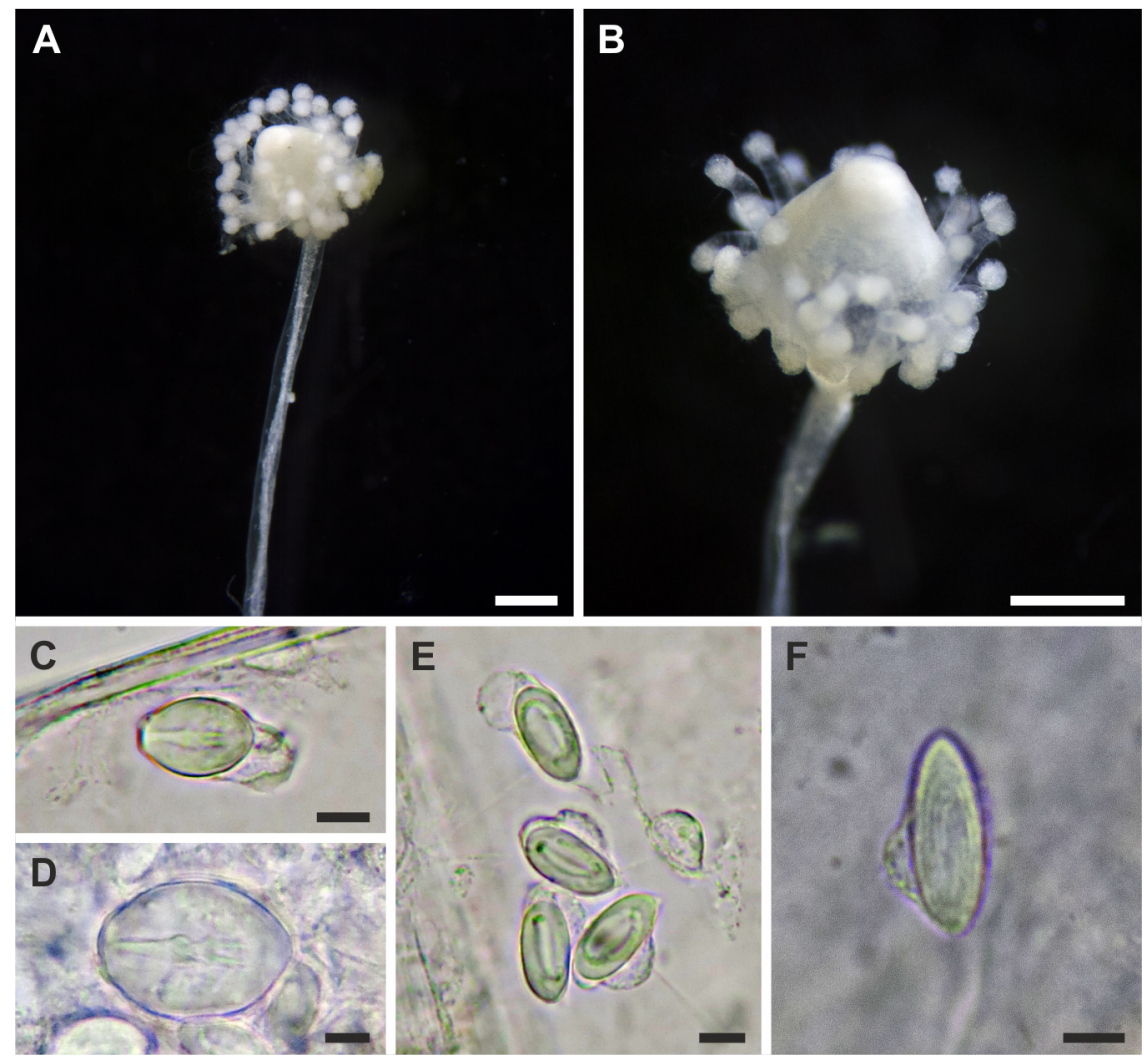

FIGURE 5 Euphysilla sp. A, B) Ethanol-fixed polyps from Martinique. C) Desmonemes, D) small and E) large stenoteles, and F) heteronemes from the polyp. Scale bars: A, B) $50 \mu \mathrm{m}$; C-F) $5 \mu \mathrm{m}$.

to 40 tentacles whose arrangement was not clear in preserved specimens, each with a terminal, nematocyst-rich capitulum. Small

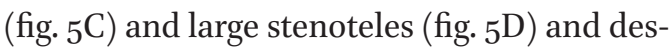
monemes (fig. $5 \mathrm{E}$ ) occurring simultaneously and concentrated in the capitula, found also in the hydrocaulus; heteronemes rarely found in the hydrocaulus (fig. $5^{\mathrm{F}}$ ).

Polyp cnidome. i) Desmonemes (undischarged: $10 \times 4-5 \mu \mathrm{m})$. ii) Heteronemes (undischarged: $16 \times 7$ ). iii) Large stenoteles (undischarged: $22-24 \times 12-15 \mu \mathrm{m}$ ). iv) Small stenoteles (undischarged: 11-14 × 8-10 $\mu \mathrm{m}$ ).

Distribution: Currently only known from the Caribbean Sea (Martinique, Panama).

Remarks: This species was identified as belonging to the genus Euphysilla based on genetic data alone, since no comprehensive information on its polyp stage was available (e.g., colour of living polyps). Additionally, the medusa stage is currently unknown. However, the general morphology and the cnidome composition and size are comparable to those of E. pyramidata. Other than $E$. pyramidata, the genus Euphysilla currently includes two additional species, namely E. peterseni Allwein, 1967, and E. tubularia Huang, Xu \& Lin, 2015, from NW Atlantic and China Sea, respectively (Allwein, 1967; Huang et al., 2015). Morphological differences among the medusae of Euphysilla species are only slight and they might represent intraspecific variation. However, the finding of another Euphysilla species based on genetic data may support the presence of multiple species, and our material may be later demonstrated to 
be conspecific with E. peterseni, E. tubularia, or other species. The medusae identified by Bouillon (1978) as E. pyramidata lack an apical chamber and have a different bell shape. It is likely distinct from E. pyramidata and thus another potential candidate that could be the medusa of the present species.

\section{Heterocoryne Wedler \& Larson, 1986}

Diagnosis: Hydroid colony stolonal; hydrocaulus unbranched; hydranth vasiform, with one whorl of long capitate tentacles and one whorl of tentacles that are composed of two to four parallel, partially-fused capitate tentacles. Gonophores single, on short pedicel, among upper whorl of simple capitate tentacles. Gonophores developing into eumedusoids.

Genetic diagnosis: 87 molecular diagnostic characters differentiate Heterocoryne from other genera in the family, specifically 21 in the $16 \mathrm{~S}, 23$ in the Cox1, 33 in the $\operatorname{Cox}_{3}, 6$ in the $18 \mathrm{~S}$, and 4 in the $28 \mathrm{~S}$ (table 2).

Remarks: Heterocoryne is a monotypic genus.

\section{Heterocoryne caribbensis Wedler \& Larson, 1986}

Heterocoryne caribbensis Wedler \& Larson, 1986: 75, figs. 2a-e; pl. 1 figs. 4-6; Galea, 2013: 9, pl. 1, figs. G-I; fig. 2m; Maggioni et al. 2017: 737 .

Examined material: Sample sTEoo1, Sint Eustatius, 07/06/2015, polyps in ethanol. Sample steoo2, Sint Eustatius, o8/06/2015, polyps in ethanol. - Sample steoo3, Sint Eustatius, 09/06/2015, polyps in ethanol. Sample STEo11, Sint Eustatius, 12/06/2015, polyps in ethanol and formalin. -Sample STE014, Sint Eustatius, 13/06/2015, polyps in ethanol and formalin. - Sample sTEo18, Sint Eustatius, 13/06/2015, polyps in ethanol. - Sample STE028, Sint Eustatius, 15/06/2015, polyps in ethanol and formalin. - Sample STE043, Sint Eustatius, 19/06/2015, polyps in ethanol and formalin. - Sample sTE046, Sint
Eustatius, 20/06/2015, polyps in ethanol. Sample MHNG-INVE-oo6967o, Guadeloupe, o3/12/2009, polyps in ethanol.

Description: Polyp. Colonies monomorphic, living in association with sponges (figs. 6A-C). Hydrorhiza tubular, branched, covered by perisarc and growing within sponge host. Pedicels unbranched, covered by a thin perisarc and by the sponge, the latter forming a cone-shaped cover around the base of the polyp (fig. 6C). Hydranth pyriform, up to $3.5 \mathrm{~mm}$ long, with variable diameter $(160-630 \mu \mathrm{m})$. Hypostome proboscis-like. One whorl of up to eight capitate tentacles below the hypostome and one whorl of up to 12 aboral capitate tentacles, each one provided with two or three partially-fused capitate tentacles on the proximal side (figs. $6 \mathrm{D}, \mathrm{E})$. Each tentacle with a terminal, nematocyst-rich capitulum (diameter: $95^{-130} \mu \mathrm{m}$ ), with a central inclusion (lost in fixed material). Tentacles up to $1 \mathrm{~mm}$ long. One fixed gonophore (eumedusoid) per polyp, among oral tentacles. Living hydranths with white hypostome, and a reddish gastric cavity (figs. 6A-C). Desmonemes, small and large stenoteles (fig. $6 \mathrm{~F}$ ) occurring in the capitula, and rarely scattered in the hydrorhiza and in the hydranth.

Polyp cnidome. i) Desmonemes (undischarged: $8-9 \times 4-5 \mu \mathrm{m}$; discharged capsule: $7 \times 4-5 \mu \mathrm{m}$ ). ii) Large stenoteles (undischarged: $16-19 \times 11-13 \mu \mathrm{m}$; discharged capsule: 13-16 × 10-11 $\mu \mathrm{m}$ ). iii) Small stenoteles (undischarged: $10-12 \times 6-7 \mu \mathrm{m}$; discharged capsule: $8-9 \times 5 \mu \mathrm{m})$.

Distribution: Presumably endemic to the Caribbean Sea (currently only known from Guadeloupe, Martinique, Puerto Rico, Sint Eustatius, US Virgin Islands).

Remarks: The analysed colonies fully agree with the specimens analysed by previous authors, both in general morphology and cnidome composition (Wedler \& Larson, 1986; Galea, 2013). A minor difference is the presence, in some polyps, of four instead of three tentacles in the aboral whorl. 

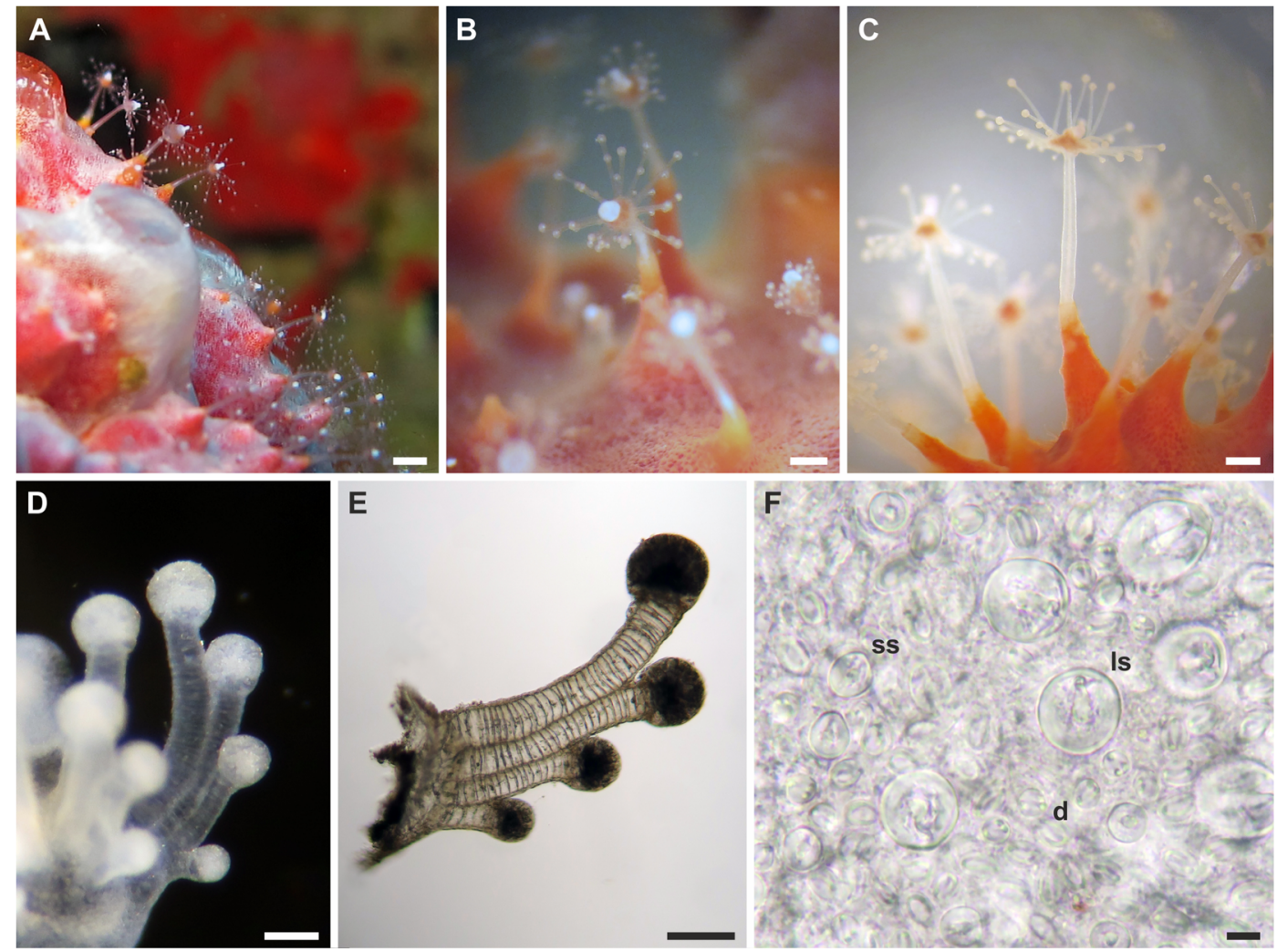

FIgURE 6 Heterocoryne caribbensis. A-C) Polyps from Sint Eustatius. D, E) Tentacles partially fused. F) Large stenoteles (ls), small stenoteles (ss), and desmonemes (d). Scale bars: A-C) 0.5 mm; D, E) $0.1 \mathrm{~mm}$; F) $5 \mu \mathrm{m}$.

\section{Family Zancleopsidae Bouillon, 1978}

Diagnosis: Polyps known for Zancleopsis only; colonies stolonal; hydrocaulus short to moderately long, simple, arising from a hydrorhiza embedded in host sponge; perisarc thin, covering both the hydrorhiza and the hydrocaulus; hydranth slightly pyriform to cylindrical, with proboscis-like hypostome and dicapitate tentacles in one or two alternating whorls around broadest part of body; gonophores developing among tentacles as free medusae.

Medusa with conical or dome-shaped umbrella, with or without apical projection; manubrium flask-shaped, with quadrate or cruciform base, mouth simple, cruciform or circular, with or without lips; two or four tentacles, with or without capitate branches; bulbs with adaxial hemispherical projections equipped with nematocysts; with or without abaxial ocelli; gonads aradial to interradial, with interradial grooves.

\section{Zancleopsis Hartlaub, 1907}

Diagnosis: As for the family, but medusae when fully mature with four tentacles, the two opposite pairs differing also in size and morphology.

Remarks: The following nominal species are currently included in this genus: Zancleopsis cabela (Maggioni et al., 2017); Z. dichotoma (Mayer, 1900); Z. elegans Bouillon, 1978; Z. gotoi (Uchida, 1927); Z. oblonga Xu, Huang \& Wang, 2016; Z. symmetrica Bouillon, 1985; Z. tentaculata Kramp, 1928.

\section{Zancleopsis dichotoma (Mayer, 1900)}

Gemmaria dichotoma Mayer, 1900: 35, pl. 17 fig. 40. 
Zancleopsis dichotoma. Hartlaub, 1907: 115, fig. 105; Schuchert \& Collins, 2021 (small form): 272, fig. 22.

Examined material: Sample sNo35, Singapore, $28 / 11 / 2017$, polyps in ethanol and formalin. - Sample BFLA4170, off Florida, o9/o8/2019, medusa in ethanol and in situ photos. Sample BFLA4171, off Florida, o9/o8/2019, medusa in ethanol and in situ photos. $-S$ ample BFLA4248, off Florida, 23/11/2019, medusa in ethanol and in situ photos.

Description: Polyp. Colonies monomorphic, living in association with sponges (fig. $7 \mathrm{~A}$ ). Hydrorhiza tubular and covered by a thin perisarc, embedded by the sponge host. Pedicels short and completely embedded in the sponge host, unbranched, covered by a thin perisarc. Hydranth slightly pyriform, up to $0.7 \mathrm{~mm}$ long, with variable diameter $(110-170 \mu \mathrm{m})$ (fig. $7 \mathrm{~A}, \mathrm{~B}$ ). Hypostome proboscis-like (fig. $7 \mathrm{~B}$ ). Tentacles organised in two alternating whorls of $4-5$ tentacles (fig. $7 \mathrm{~A}$ ). Each tentacle with terminal and sub-terminal capitula (diameter: $60-100 \mu \mathrm{m}$ in the distal whorl; $40-50 \mu \mathrm{m}$ in the proximal whorl) (fig. ${ }_{7} \mathrm{C}$ ). Tentacles about $260-400 \mu \mathrm{m}$ long in the distal whorl, shorter in the proximal whorl (about 150-220 $\mu \mathrm{m})$. Nematocyst clusters $5^{\mathrm{O}-100} \mu \mathrm{m}$ distant from one other. Living hydranths transparent. Desmonemes, microbasic euryteles, small and large stenoteles (figs. $7 \mathrm{D}, \mathrm{E}$ ) occurring simultaneously and concentrated in the capitula, as well as scattered in the hydrorhiza; microbasic euryteles also in the hydranth.

Polyp cnidome. i) Desmonemes (undischarged: $7-9 \times 4 \mu \mathrm{m}$; discharged capsule: $6 \times$ $3 \mu \mathrm{m})$. ii) Microbasic euryteles (undischarged:

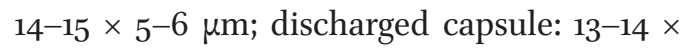
$5^{-6} \mu \mathrm{m}$; shaft: $\left.17-20 \mu \mathrm{m}\right)$. iii) Large stenoteles (undischarged: $22-23 \times 14-16 \mu \mathrm{m}$; discharged capsule: $13 \times 20 \mu \mathrm{m})$. iv) Small stenoteles (undischarged: $9-10 \times 6-7 \mu \mathrm{m}$; discharged capsule: $7 \times 9 \mu \mathrm{m})$.
Adult medusa (from Schuchert \& Collins, 2021, small form only). Total bell height up to $3 \mathrm{~mm}, 1 / 4$ to $1 / 3$ of the height taken by pointed apical process (fig. $7 \mathrm{~F}, \mathrm{G}$ ); umbrella bellshaped to conical, relatively thick walls, with shallow interradial subumbrellar pockets, tip of apical process green. Manubrium height about half the subumbrellar height when gonads start to develop, pear-shaped, short tubular oral part, mouth rim with four perradial white regions, upper part of manubrium (stomach) ochre coloured, with about 10 longitudinal, shallow gonad folds, folds mostly adradial, irregular (fig. $7 \mathrm{H}$ ). Radial canals not forming mesenteries, smooth. Tentacle bulbs all equally developed, almost spherical, placed adaxial of origin of tentacles, white or faintly yellow. Two long, opposite tentacles, much extendable/contractible, with up to 25 short, abaxial, side branches ending in capitula, size of capitula gradually increasing towards distal (fig. $7 \mathrm{I}$ ). The other tentacle pair very short, ending in spherical nematocyst knob. In young animals these short tentacles either missing or just beginning to develop. All tentacle bases with a red ocellus on abaxial side.

Adult medusa cnidome (preserved tissue). i) Desmonemes $(8.5 \times 5 \mu \mathrm{m})$. ii) Small stenoteles $(18-21 \times 14-17)$. iii) Larger stenoteles $(24-26$ $\times 22-23 \mu \mathrm{m})$. iv) Macrobasic euryteles $\left(15^{-16}\right.$ $\times 6-7 \mu \mathrm{m}$.

Distribution: Atlantic Ocean (Florida) and Indo-West Pacific (Singapore).

Remarks: Schuchert \& Collins (2021) found that $Z$. dichotoma medusae were genetically similar to A. cabela polyps. However, they found two genetically divergent morphs, one smaller (bell height of $3 \mathrm{~mm}$ ) and the other larger (bell height up to $15 \mathrm{~mm}$ ). The small morph better agrees with the original description of Z. dichotoma by Mayer (1900), and it was here linked through genetic data to Astrocoryne-like polyps from Singapore, 


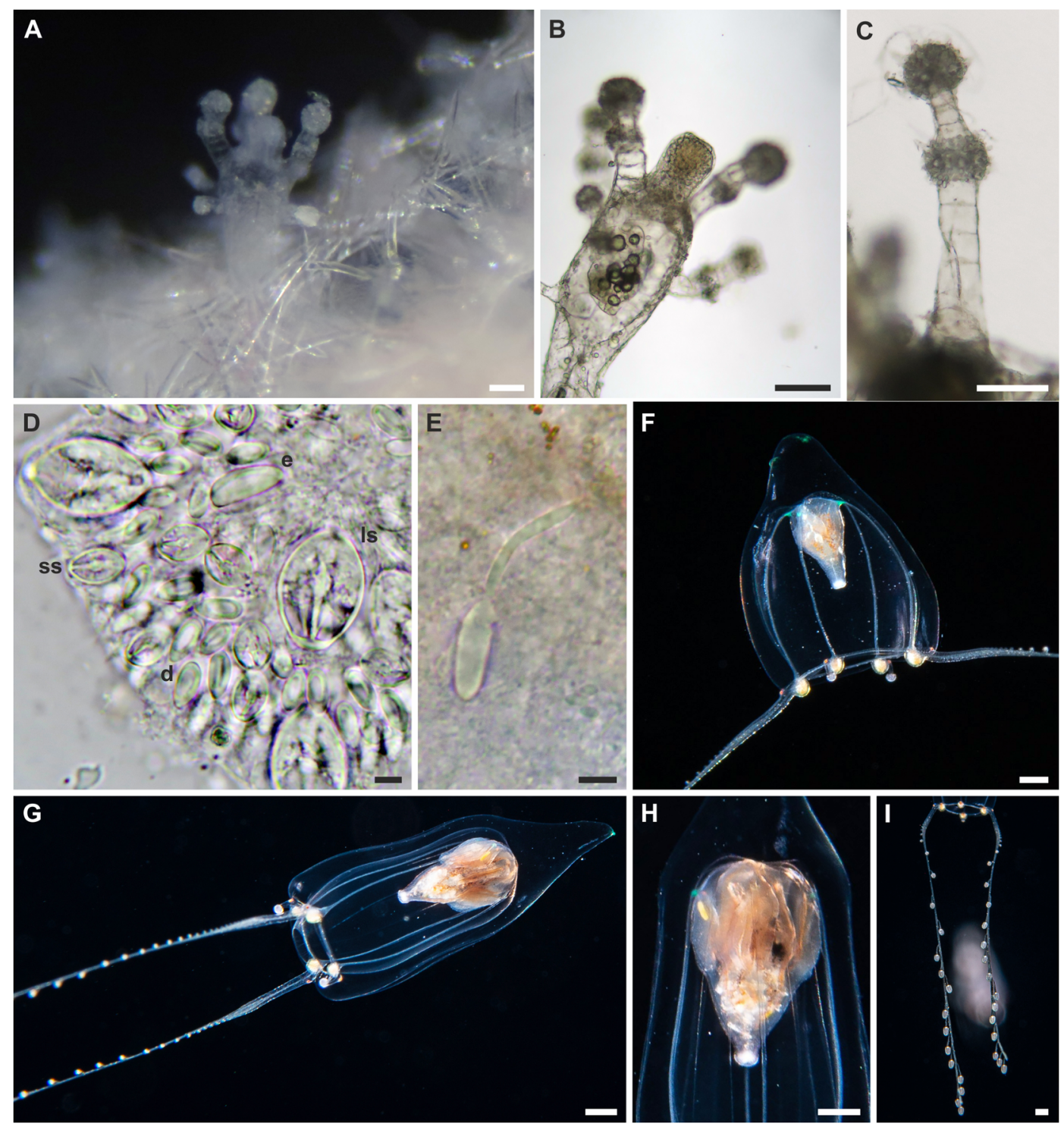

FIGURE 7 Zancleopsis dichotoma. A) Polyp from Singapore (fixed in formalin). B) Close-up of a polyp. C) Tentacle with terminal and sub-terminal capitula. D) Large stenoteles (ls), small stenoteles (ss), desmonemes (d), and microbasic euryteles (e). E) Discharged microbasic eurytele. F, G) Medusae. Details of the H) manubrium with gonads and I) tentacles. Scale bars: A-C) $0.1 \mathrm{~mm}$; D, E) $5 \mu \mathrm{m}$; F-I) 0.3 mm.

supporting the synonymisation of the genus Astrocoryne with Zancleopsis.

\section{Zancleopsis cabela (Maggioni et al., 2017) comb. nov.}

Zancleopsis dichotoma. Bigelow, 1938: 102, figs 1-2; Schuchert \& Collins, 2021 (large form): 272 , fig. 23 .
Astrocoryne cabela Maggioni et al., 2017: 737, figs. 2-4.

Examined material: Sample MA16053, Maldives, o8/02/2016, polyps in ethanol and formalin (MSNM-Coe-341) and young medusae in formalin (MSNM-Coe-342). - Sample MA16o52, Maldives, o8/o2/2016, 
polyps in ethanol and formalin. - Sample MA1016o13, Maldives, 12/10/2016, polyps in ethanol and formalin. - Sample KA175, Saudi Arabia 17/12/2015, polyps in ethanol. -Sample BFLA4408, off Florida, 26/05/2020, part of medusa in ethanol and in situ photos. - Sample BFLA4467, off Florida, 17/o6/2020, medusa in formalin (UF-014O72), ethanol and in situ photos.

Description: Polyp. Colonies monomorphic, living in association with sponges (figs. 8A-C). Hydrorhiza tubular, covered by moderately thick and slightly wrinkled perisarc, embedded by the sponge host. Pedicels short to moderately long (up to $580 \mu \mathrm{m}$ ), unbranched, covered by a smooth, thin, cup-shaped or elongated perisarc. Hydranth pyriform or slightly pyriform, up to $0.8 \mathrm{~mm}$ long, with variable diameter (up to $250 \mu \mathrm{m}$ ). Hypostome proboscis-like, contractile. Up to 10 tentacles (range 8-10) arranged in one or two close whorls in the broadest part of the polyp. Each tentacle with terminal and sub-terminal capitula (diameter: 50-110 $\mu \mathrm{m}$ in the distal whorl; 25-45 $\mu \mathrm{m}$ in the proximal whorl) (fig. 8D). Tentacles up to $550 \mu \mathrm{m}$ long in the distal whorl, shorter in the proximal whorl (up to $320 \mu \mathrm{m}$ ) when present. Nematocyst clusters about 100 $\mu \mathrm{m}$ distant from one other, closer when tentacles are contracted. Up to 11 medusa buds at different stages of maturation develop among tentacles, singly or in couple on blastostyles (fig. 8E). Living hydranths transparent, with white mouths and whitish or light orange gastric cavities. Desmonemes, microbasic euryteles, small, large and medium-sized stenoteles (figs. 8F, G) occurring simultaneously in the terminal and proximal capitula, and in the hydrorhiza, rare in the hydranth.

Newly liberated medusa. Newly liberated medusa hemispherical, up to $500 \mu \mathrm{m}$ wide and high, with nematocysts scattered on the exumbrella. Manubrium cylindrical, up to
$200 \mu \mathrm{m}$ long and 110 wide at the base, spanning from $1 / 3$ to $1 / 2$ of the bell height, distally provided with a circular mouth. Four radial canals ending in four bulbs with a diameter of up to $70 \mu \mathrm{m}$, and a circular canal. Bulbs and circular canals containing nematocysts. At release medusae with no tentacles, but with bulbs showing swellings filled with nematocysts. Two opposite tentacles after two days from release. Tentacles up to $300 \mu \mathrm{m}$ long, with terminal spherical nematocyst-rich capitula with a diameter of up to $85 \mu \mathrm{m}$. Ocelli absent at release. Microbasic mastigophores and rarely microbasic euryteles scattered on the exumbrella, medium-sized stenoteles in the circular canal, medium-sized stenoteles and desmonemes in the bulb swellings and in the terminal capitula of tentacles.

Polyp and newly liberated medusa cnidome.

i) Desmonemes (undischarged: 7-9 $\times 4-5$ $\mu \mathrm{m}$; discharged capsule: $6-8 \times 4-5 \mu \mathrm{m})$. ii) Microbasic euryteles (undischarged: $13-15 \times$ 5-6 $\mu \mathrm{m}$; discharged capsule: $10-12 \times 4-5 \mu \mathrm{m}$; shaft: $9-11 \mu \mathrm{m}$ ). iii) Large stenoteles (undischarged: $18-21 \times 13-17 \mu \mathrm{m}$; discharged capsule: 15-18 × 11-15 $\mu \mathrm{m})$. iv) Medium-sized stenoteles (undischarged: 9-10 $\times 6-7 \mu \mathrm{m}$; discharged capsule: $8-9 \times 5 \mu \mathrm{m}$ ). v) Small stenoteles (undis-

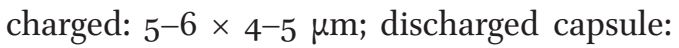
$5 \times 4-5 \mu \mathrm{m})$. vi) Microbasic mastigophores (undischarged: $6-7 \times 5^{-7} \mu \mathrm{m}$; discharged capsule: $5 \times 5 \mu \mathrm{m}$; shaft: $5 \mu \mathrm{m})$.

Adult medusa (from Schuchert \& Collins, 2021, Z. dichotoma large form). Similar but much larger than $Z$. dichotoma (= small form), height 8 to $15 \mathrm{~mm}$ and $5 \mathrm{~mm}$ diameter, apical process larger reaching $1 / 2$ of total height, tip of apical process whitish, more and larger vertical gonad folds, approximately up to 15 , grouped in $2-3$ folds adradial, brownish, oocytes yellow, tentacle bulbs with intense yellow colour, shorter tentacle pair longer than in Z. dichotoma (figs. 8H-K). 


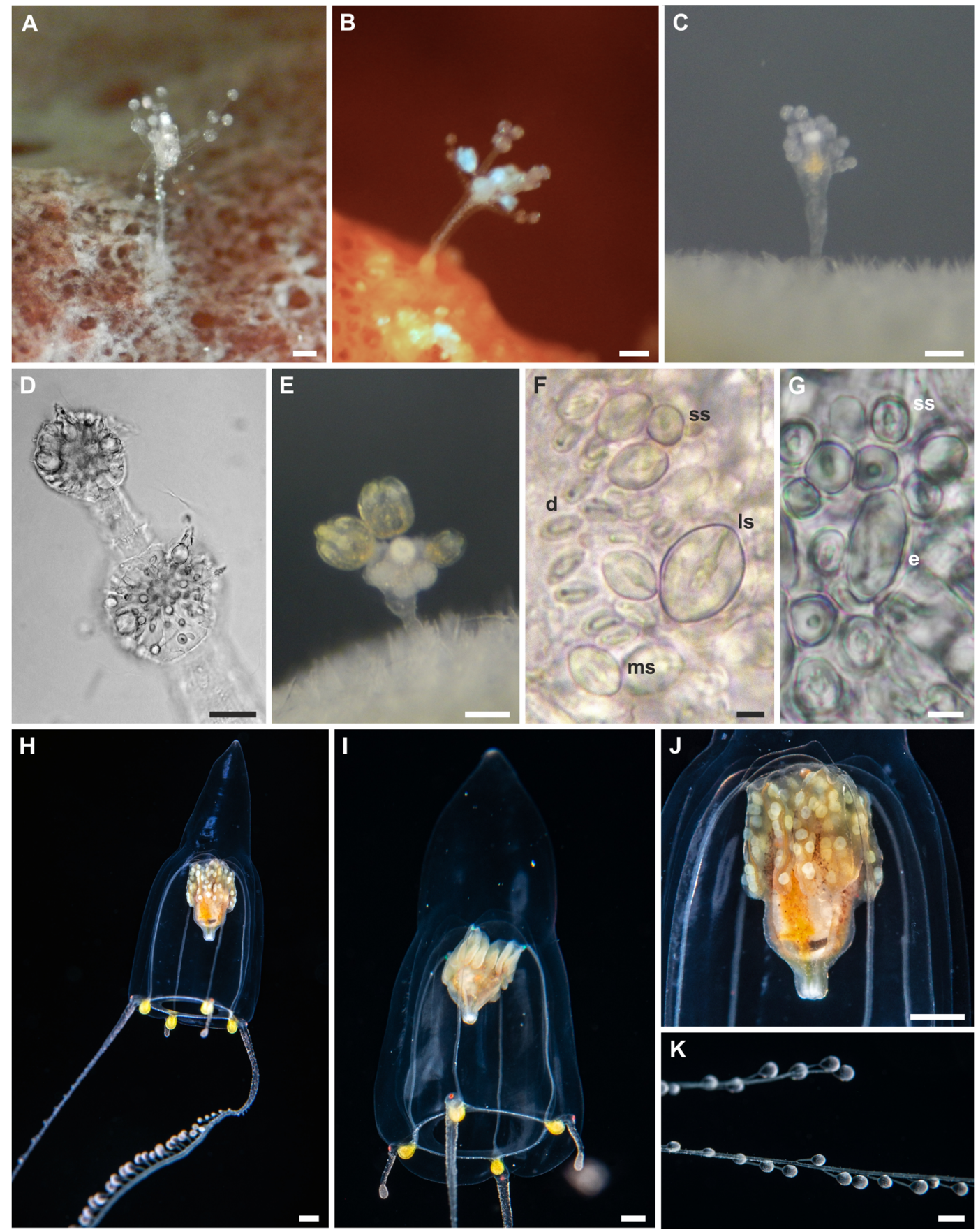

FIgUre 8 Zancleopsis cabela. Polyps from A) Saudi Arabia and B, C) Maldives. D) Tentacle with terminal and sub-terminal capitula. E) Maldivian polyp with medusa buds. F) Large stenoteles (ls), medium-sized stenoteles (ms), small stenoteles (ss), and desmonemes (d). G) small stenoteles (ss) and microbasic euryteles (e). H, I) Female and male medusae, respectively. Details of J) manubrium with female gonads and K) tentacles. Scale bars: A-C, E) $0.2 \mathrm{~mm}$; D) $50 \mu \mathrm{m} ; \mathrm{F}, \mathrm{G}) 5 \mu \mathrm{m}$; H-K) $1 \mathrm{~mm}$. 
Distribution: Atlantic Ocean (Bermuda, Florida), and Red Sea and Indo-West Pacific (Saudi Arabia; Maldives).

Remarks: The polyp stage of this species was previously identified as $A$. cabela, but genetic data allowed us to link it to the large morph of Z. dichotoma described by Schuchert \& Collins (2021), further confirming the synonymisation of Astrocoryne with Zancleopsis. The main differences to $Z$. dichotoma are a larger adult medusa and larger polyps with tentacles less regularly organised. Kramp (1968) suspected that Z. dichotoma and Zancleopsis tentaculata Kramp, 1928 could be conspecific. Zancleopsis tentaculata (type locality: Banda Sea, Indonesia) generally shows a larger size and the short tentacles are longer than in $Z$. dichotoma, something shared with $Z$. cabela. However, given the uncertainties in the morphological identification of $Z$. tentaculata we prefer to ascribe these specimens to Z cabela, because genetic data of the type material of A. cabela were included in the analyses.

\section{Zancleopsis sp.}

Examined material: Sample sNoo6, Singapore, $28 / 11 / 2017$, polyps in ethanol and formalin. - Sample SN117, Singapore, 30/11/2017, polyps in ethanol and formalin. - Sample SN12O, Singapore, 30/11/2017, polyps in ethanol and formalin. - Sample SN143, Singapore, o1/12/2017, polyps in ethanol and formalin.

Description: Polyp. Colonies monomorphic, living in association with sponges (figs. 9A-C). Hydrorhiza tubular and covered by a thin perisarc, embedded by the sponge host. Pedicels short and completely embedded in the sponge host, unbranched, covered by a thin perisarc. Hydranth cylindrical to slightly pyriform, up to $0.75 \mathrm{~mm}$ long, with variable diameter $(80-150 \mu \mathrm{m})$ (figs. 9AD). Hypostome proboscis-like. Tentacles organised in two alternating whorls of $4-5$ tentacles (figs. 9C-D). Each tentacle with terminal and sub-terminal capitula (diameter: 80-100 $\mu \mathrm{m}$ in the distal whorl; 40-70 $\mu \mathrm{m}$ in the proximal whorl) (fig. $9 \mathrm{E}$ ). Tentacles $35 \mathrm{O}^{-}$ $380 \mu \mathrm{m}$ long in the distal whorl, shorter in the proximal whorl (about $250 \mu \mathrm{m}$ ). Nematocyst clusters about $50-80 \mu \mathrm{m}$ distant from one other. Living hydranths transparent, with white mouths (figs. 9A-C). Desmonemes, microbasic euryteles, small and large stenoteles (figs. $9 \mathrm{~F}-\mathrm{H}$ ) occurring simultaneously and concentrated in the capitula, as well as scattered in the hydrorhiza; microbasic euryteles also scattered in the hydranth.

Polyp cnidome. i) Desmonemes (undischarged: $7-8 \times 4-5 \mu \mathrm{m}$; discharged capsule: $6 \times 4 \mu \mathrm{m}$ ). ii) Microbasic euryteles (undischarged: $13-14 \times 4-6 \mu \mathrm{m}$; discharged capsule: $12 \times 5 \mu \mathrm{m}$; shaft: $20 \mu \mathrm{m})$. iii) Large stenoteles (undischarged: $20-23 \times 13-14 \mu \mathrm{m}$; discharged capsule: $19 \times 13 \mu \mathrm{m})$. iv) Small stenoteles (undischarged: $9-10 \times 6-7 \mu \mathrm{m}$; discharged capsule: $9 \times 6 \mu \mathrm{m})$.

Distribution: Only known from the IndoWest Pacific (Singapore).

Remarks: This species has polyps that are apparently identical to those of $Z$. dichotoma in both general morphology and cnidome, and was separated from the latter based on molecular data alone, nevertheless showing high genetic divergence. Since the adult medusa is unknown, it is currently not possible to identify these colonies to the species level using morphology alone. Because it could additionally also belong to an already named medusa, we prefer here not to give it a new species name, also because all the other Zancleopsis species not sampled in this work have their type localities in the Western Pacific, namely in the Banda Sea, Bismarck Sea, South China Sea, and Japan (Uchida, 1927; Kramp, 1928; Bouillon, 1978, 1985; Wang et al., 2016). 

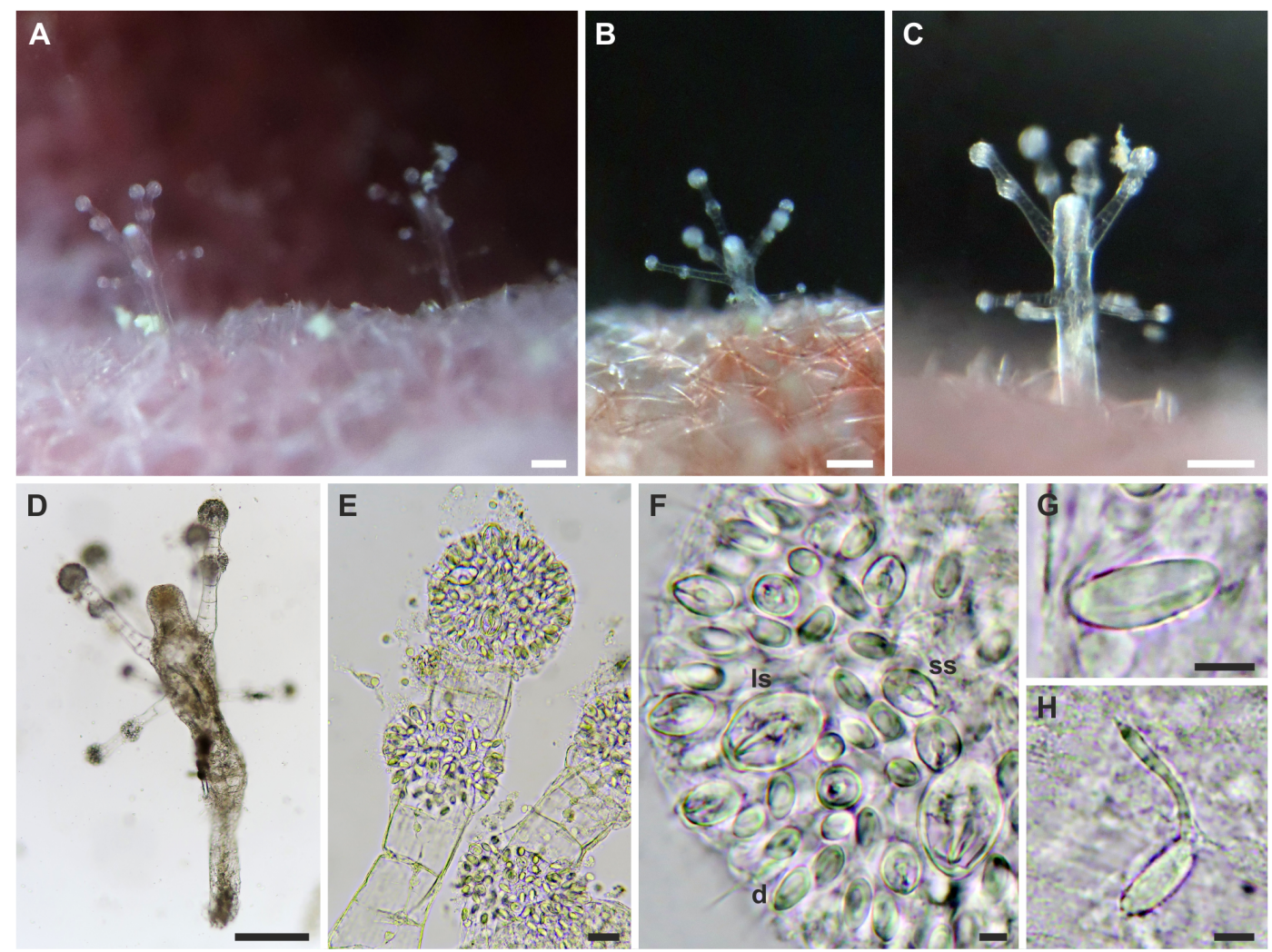

FIGURE 9 Zancleopsis sp. A-C) Polyps from Singapore. D) Close-up of a polyp. E) Tentacle with terminal and subterminal capitula. F) Large stenoteles (ls), small stenoteles (ss), and desmonemes (d). G) undischarged and H) discharged microbasic eurytele. Scale bars: A-D) $0.2 \mathrm{~mm}$; E) $20 \mu \mathrm{m}$; F-H) $5 \mu \mathrm{m}$.

\section{Distribution and geographic structure}

Distributional maps were built for all analysed species, based on both data from this study and literature records (fig. 10, supplementary table $\left.\mathrm{S}_{4}\right)$. Sphaerocoryne bedoti and E. pyramidata showed wide and overlapping distributions (figs. 10A, B), with occurrences in the Atlantic, Pacific, and Indian Oceans, and the Red Sea. Kudacoryne diaphana, on the other hand, showed a distribution currently limited to the Indian Ocean and Red Sea (fig. $10 \mathrm{C})$, and overlapping with the aforementioned sphaerocorynid species. Heterocoryne caribbensis showed a distribution limited to the Eastern Caribbean Sea (fig. 1oE), supporting the hypothesis of it being endemic to the Caribbean region. Similarly, Euphysilla sp. was found only in Caribbean localities (fig. 1oD). Zancleopsis dichotoma showed a wide distribution, spanning the Atlantic and Pacific Oceans (fig. 10F). Similarly, also Z. cabela was demonstrated to have a wide distributional range, being found in both the Atlantic and Indian Oceans and the Red Sea (fig. 10G). Finally, Zancleopsis sp. is currently known only from the Indo-West Pacific (Singapore) (fig. 10H).

Haplotype networks of Sphaerocoryne bedoti, Kudacoryne diaphana, and Euphysilla pyramidata based on the $16 \mathrm{~S}$ region revealed a moderate geographic structure for all species (fig. 11). Indeed, no haplotypes were shared among localities, being all haplotypes from different localities well separated from each other in all investigated species. 
A) Sphaerocoryne bedoti

B) Euphysilla pyramidata

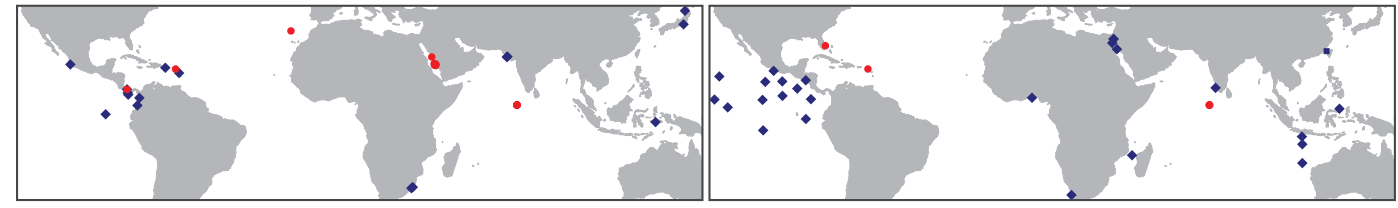

C) Kudacoryne diaphana

D) Euphysilla sp.

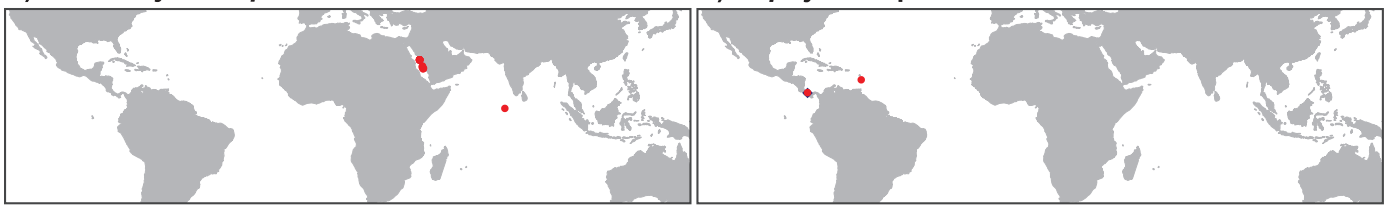

E) Heterocoryne caribbensis

F) Zancleopsis dichotoma

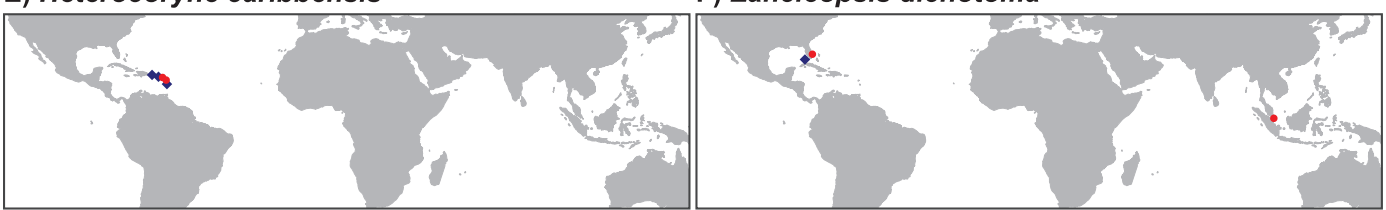

G) Zancleopsis cabela

H) Zancleopsis sp.

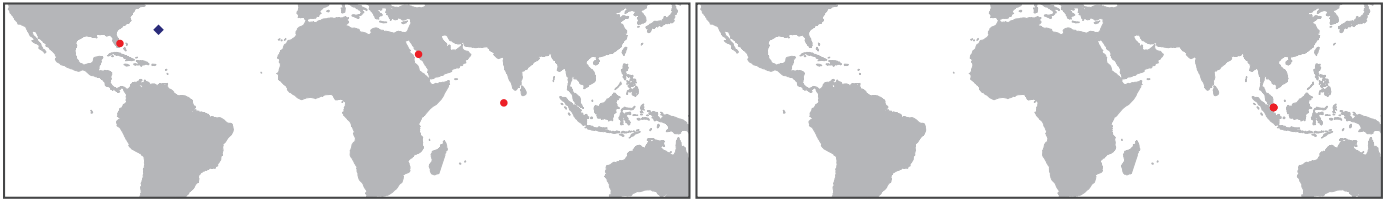

FIGURE 10 Distributional maps of each analysed species. A) Sphaerocoryne bedoti. B) Euphysilla pyramidata.

C) Kudacoryne diaphana. D) Euphysilla sp. E) Heterocoryne caribbensis. F) Zancleopsis cabela. G) Zancleopsis dichotoma. $\mathrm{H}$ ) Zancleopsis sp. Red circles represent data from this study, whereas blue diamonds represent data from literature.

\section{Discussion}

The integrative scope of the present work disentangled some of the taxonomic uncertainties affecting the families Sphaerocorynidae and Zancleopsidae. Indeed, the morpho-molecular approach enabled us to accurately characterise the analysed species, to identify the previously unknown polyp stages of Euphysilla and Zancleopsis, to describe a new sphaerocorynid genus and species (both authored by Maggioni), and to assess the phylogenetic position of the two families within the Capitata. Molecular species delimitations concordantly revealed the presence of ten species hypotheses in the investigated dataset, and also genetic distances between species were always moderate to high, not overlapping with intraspecific distances, with values comparable to other closely related capitate species (e.g., Miglietta et al., 2019; Maggioni et al., 2O2Oa, b, 2021). Morphological analyses identified diagnostic and easy-to-detect features of sphaerocorynid polyps, mostly related to the colour of hydranths, tentacles organisation, inclusions in capitula, and organisation of medusa buds. Other than these differences, sphaerocorynid polyps show a consistent morphology, with a pyriform hydranth, proboscis-like hypostome and tentacles organised in close whorls in the broadest part of the hydranth. For these reasons, a genetic diagnosis for each genus was also provided. Polyps of the three Zancleopsis species analysed in this work were very similar to each other, making it difficult to identify them without medusa or genetic information. 
A) Sphaerocoryne bedoti

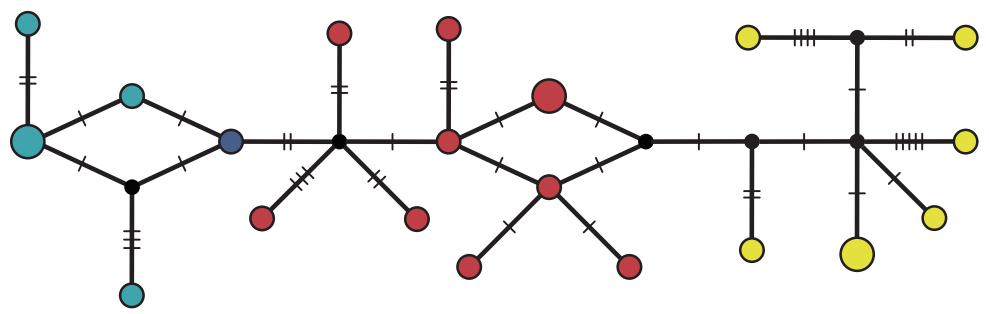

B) Kudacoryne diaphana

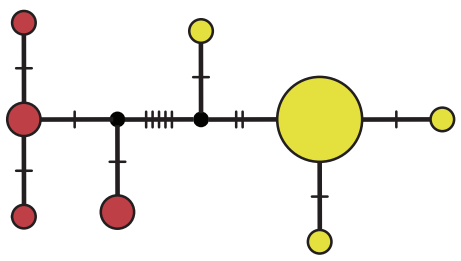

C) Euphysilla pyramidata

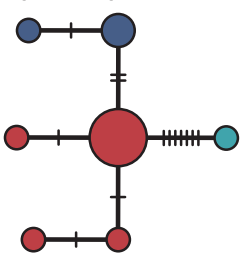

$\begin{array}{llll}10 & \text { Caribbean Sea } & \text { Indian Ocean } \\ \text { (1) Atlantic Ocean } & \bigcirc \text { Red Sea }\end{array}$

FIGURE 11 Most parsimonious median-joining haplotype networks based on the $16 \mathrm{~S}$ of A) S. bedoti, B)

E. pyramidata, and C) K. diaphana, with haplotypes coloured by locality, as shown in the legend.

A common feature of sphaerocorynid and zancleopsid polyps is the frequent association with sponges, also seen among some zoantharians, which belong to Anthozoa (e.g., Reimer et al., 2018; Montenegro et al., 2020). Previous reports and the present study highlighted that occasional associations with other substrates are also possible in the family Sphaerocorynidae, namely with coralline algae, dead and living corals (Calder et al., 2003), coral rubble (Calder, 2010), bivalves (Calder, 1971), serpulid tubes (Galea, 2008), and other hydrozoans (Mergner \& Wedler, 1977). However, with a few exceptions for $S$. bedoti and E. pyramidata, all other samples analysed in this work were associated with sponges. Capitate hydrozoans often establish symbiotic associations with benthic invertebrates, such as scleractinian corals, octocorals, bryozoans, and bivalves (Cerrano et al., 1997; Maggioni et al., 2016, 2020c, d), in some cases with high specificity (e.g., Montano et al., 2017a; Maggioni et al., 2020a) and hypothesised important ecological roles for their hosts (Montano et al., 2017b). On the other hand, they can also be hosts themselves to anthoathecate hydrozoans (Montano et al., 2020). Regarding sphaerocorynid species, little is known about the specificity and the possible outcomes of their association with sponges. Indeed, the taxonomic confusion that has characterised the family for a long time, together with the difficulties hampering sponge taxonomy (Wörheide \& Erpenbeck, 2007) and the low number of previous works reporting the identification of the host sponge (e.g., Calder 1971; Yamada \& Konno, 1973; Wedler \& Larson, 1986), prevent precise speculations on this aspect. Nevertheless, an overall lack of specificity can be hypothesised, given that the same host can be shared by different species (Maggioni et al., 2017). In the same way, it is also possible that Zancleopsis species are generalist symbionts of poriferans, with Z. cabela hosted by three different sponge species in the Maldives and Red 
Sea (Maggioni et al., 2017). Future increased efforts in sponge host identification will likely shed light on the degree of specificity of these associations and may also help with the delineation of species boundaries in the associated hydrozoans, as in other species (Maggioni et al., 2O2Oa, 2O21).

Regarding the adult medusae, in this work we were able to thoroughly characterise three species, namely E. pyramidata, $Z$. dichotoma, and $Z$. cabela, whereas for the other species only the newly released medusae were observed, when found, with the exception of $H$. caribbensis that has fixed gonophores. Given the lack of material of the medusa stage, two species (i.e., Euphysilla sp. and Zancleopsis sp.) could not be identified to the species level, and may be demonstrated in the future to correspond to already described medusa-based species not analysed in this work. Similarly, the new polyp-based species Kudacoryne diaphana (authored by Maggioni) was herein erected to allow the establishment of the new genus Kudacoryne (authored by Maggioni), based on both morphological and genetic data, and we cannot exclude that this species will later be synonymised with one of the sphaerocoynid species based solely on the adult medusa stage. Notably, the unavailability of these latter species among the analysed samples left unresolved some taxonomic issues. In particular, the morphological re-description and the genetic analysis of S. agassizii material is needed to address the validity of the genus Sphaerocoryne (Calder, 2010; Schuchert, 2010).

The phylogenetic hypotheses presented allowed the identification of a sister-group relationship between the Sphaerocorynidae and Zancleopsidae, an aspect already hypothesised in previous morphology-based cladistic analyses (Petersen, 1990), in which the presence of medusa tentacular bulbs with adaxial expansions was considered to be a synapomorphy of the two families. In that analysis, Petersen (1990) also placed these two families together with Paragotoea Kramp, 1942, forming the superfamily Sphaerocorynoidea, and with the Hydrocorynidae Rees, 1957, forming the suborder Sphaerocorynida, finding that the long, capitate, aboral tentacles of polyps, arranged in close-set whorls, could be a synapomorphy of the suborder. However, later DNA-based phylogenetic analyses placed the Hydrocorynidae in a divergent position (e.g., Nawrocki et al., 2010), and Paragotoea is currently included in the aplanulate family Corymorphidae Allman, 1872 (Pages \& Bouillon, 1997), thus invalidating the classification system proposed by Petersen (1990) for these taxa. Also, Euphysilla was proposed to belong to the Sphaerocorynida suborder as incertae sedis, and with this work we demonstrated that it clearly belongs to the family Sphaerocorynidae.

Interestingly, the species analysed in this work showed contrasting biogeographical patterns. Based on our data and literature records, some species appear to have a wide circumtropical distributional range, such as S. bedoti and E. pyramidata, whereas other are limited to few localities, such as H. caribbensis in the Caribbean Sea, even if in some instances an extended sampling could likely widen their distribution. These mixed distributional patterns seem to be common in closely related hydrozoan species (e.g., Arrigoni et al., 2018; Miglietta et al., 2018). Here, populations from different localities also appeared well separated in some species, suggesting possible limited gene flow among localities. The wide distribution of some of the investigated species may be related to recent human-mediated dispersal, as already hypothesised for other hydrozoans (Miglietta \& Lessios, 2009; Miglietta et al., 2015), even though the observed intraspecific geographic structure may hinder this hypothesis. 
Overall, the present work has shed new light on the diversity, biogeography, and evolution of the Sphaerocorynidae and Zancleopsidae, by providing the first detailed morpho-molecular account of eight species belonging to these families. Moreover, the results provided lay the ground for future investigations to further resolve the taxonomy and systematics of these two enigmatic taxa.

\section{Acknowledgements}

The authors wish to thank all the people involved in collecting material or organising sampling campaigns: Horia Galea (Hydrozoan Research Laboratory, France), Tullia Isotta Terraneo (KAUST, Saudi Arabia), Malek Amr Gusti (KAUsT, Saudi Arabia), Timothy Ravasi (OIST, Japan), the captain and crew of the MV Dream-Master (Saudi Arabia), the KAUST Coastal and Marine Resources Core Lab, Nicholas wL Yap (NUS, Singapore), and Sudhanshi S Jain (NUS, Singapore). Authors are also grateful to Cristina G. Di Camillo (Università Politecnica delle Marche, Italy) and Maria A. Mendoza-Becerril (CONACYT, Mexico) for sharing information on sphaerocorynid samples included in previous works, and to two anonymous reviewers for their revisions that greatly improved the work. Fieldwork in Singapore was partially funded by the National Research Foundation, Prime Minister's Office, Singapore under its Marine Science R\&D Programme (MSRDP-Po3) to DH. Fieldwork at St. Eustatius was funded through a Martin Fellowship from Naturalis Biodiversity Center to SM, while logistic support was supplied by St. Eustatius Marine Parks (STENAPA), the Caribbean Netherlands Science Institute (CNSI) and Scubaqua Dive Centre. Permissions relevant to undertake the research have been obtained from the applicable governmental agencies. No conflict of interest to declare.

\section{Supplementary material}

Supplementary material is available online at: https://doi.org/10.6o84/mg.figshare.15155682

\section{References}

Allwein, J. (1967) North American hydromedusae from Beaufort, North Carolina. Vidensk. Medd. fra Dansk. Naturh. Foren., 1301, 17-136.

Arrigoni, R., Maggioni, D., Montano, S., Hoeksema, B.W., Seveso, D., Shlesinger, T., Terraneo, T. I., Tietbohl, M.D. \& Berumen, M.L. (2018) An integrated morpho-molecular approach to delineate species boundaries of Millepora from the Red Sea. Coral Reefs, 37, 967-984. https:// doi.org/10.1007/s00338-018-01739-8.

Bentlage, B. \& Collins, A.G. (2021) Tackling the phylogenetic conundrum of Hydroidolina (Cnidaria: Medusozoa: Hydrozoa) by assessing competing tree topologies with targeted highthroughput sequencing. PeerJ, 9, e12104. http:// doi.org/10.7717/peerj.12104.

Bigelow, H.B. (1909) The Medusae. Reports on the scientific results of the expedition to the eastern tropical Pacific, in charge of Alexander Agassiz, by the U.S. Fish Commission steamer 'Albatross' from October, 1904, to March, 1905. XVI. Mem. Mus. Comp. Zool. Harv. Coll., 37, 1-243.

Bigelow., H.B. (1938) Plankton of the Bermuda Oceanographic Expeditions. virI. Medusae taken during the years 1929 and 1930. Zool. Sci. Contrib. N.Y. Zool. Soc., 23, 99-189.

Boero, F. (1980) Life cycles of hydroids and hydromedusae: some cases of difficult interpretation. Mem. Biol. Marina Oceanogr., 10, 133-136.

Boero, F., Bouillon, J. \& Piraino, S. (1992) On the origins and evolution of hydromedusan life cycles (Cnidaria, Hydrozoa). Sex Origin. Evol., 6, $59-68$.

Boero, F., Bouillon, J., Piraino, S. \& Schmid, V. (1997) Diversity of hydroidomedusan life cycles: ecological implications and evolutionary 
patterns. In: J.C. den Hartog, L.P. van Ofwegen \& S. van der Spoel (Eds) Proceedings of the 6th International Conference on Coelenterate Biology, 1995, pp. 53-62. Nationaal Natuurhistorisch Museum, Leiden.

Bouckaert, R., Heled, J., Kühnert, D., Vaughan, T., Wu, C.H., Xie, D., Suchard, M.A., Rambaut, A. \& Drummond, A.J. (2014) BEAST 2: a software platform for Bayesian evolutionary analysis. PLoS Comput. Biol., 10, e1003537. https://doi. org/10.1371/journal.pcbi.1003537.

Bouillon, J. (1978) Hydromeduses de la mer de Bismarck (Papouasie, Nouvelle-Guinée). Partie 1: Anthomedusae Capitata (Hydrozoa Cnidaria). Cah. Biol. Mar., 19, 249-297.

Bouillon, J. (1984) Sphaerocoryne peterseni: Nouvelle espèce d'Anthoméduse de Papouasie Nouvelle-Guinée (Hydrozoa-Cnidaria). IndoMalayan Zool., 2, 245-248.

Bouillon, J. (1985) Notes additionelles sur les hydroméduses dela merdeBismarck (HydrozoaCnidaria). Indo-Malayan Zool., 2, 245-266.

Bouillon, J., Gravili, C., Gili, J.M. \& Boero, F. (2006) An introduction to Hydrozoa. Mémoires du Muséum Natl. d'Histoire Nat., 194, 1-591.

Brinckmann-Voss, A. (1970) Anthomedusae, Athecatae: (Hydrozoa, Cnidaria) of the Mediterranean. 1. Capitata. Fauna e Flora del Golfo di Napoli, 39, 1-96.

Buecher, E. \& Gibbons, M.J. (200o) Interannual variation in the composition of the assemblages of medusae and ctenophores in St. Helena Bay, Southern Benguela Ecosystem. Sci. Mar., 64, 123-134. https://doi.org/10.3989/scimar.20oo. 6451123.

Calder, D.R. (1971) Hydroids and hydromedusae of southern Chesapeake Bay. Virginia Inst. Mar. Sci. Spec. Papers in Mar. Sci., 1, 1-125.

Calder, D.R., Mallinson, J., Collins, K. \& Hickman, C. (2003) Additions to the hydroids (Cnidaria) of the Galápagos, with a list of species reported from the islands. J. Nat. Hist., 37, 1173-1218. https://doi.org/10.108o/oo222930110116o39.
Calder, D.R. (2010) Some anthoathecate hydroids and limnopolyps (Cnidaria, Hydrozoa) from the Hawaiian archipelago. Zootaxa, 2590, 1-91. https://doi.org/10.11646/zootaxa.259o.1.1.

Castresana, J. (2000) Selection of conserved blocks from multiple alignments for their use in phylogenetic analysis.Mol.Biol.Evol.,17,540-552. https://doi.org/10.1093/oxfordjournals.molbev. ao26334.

Cerrano, C., Amoretti, D. \& Bavestrello, G. (1997) The polyp and the medusa of Zanclea costata Gegenbaur (Cnidaria, Hydrozoa). Ital. J. Zool., 64, 177-179. https://doi. org/10.1080/11250009709356192.

Coffroth, M.A., Lasker, H.R., Diamond, M.E., Bruenn, J.A. \& Bermingham, E. (1992) DNA fingerprints of a gorgonian coral: a method for detecting clonal structure in a vegetative species. Mar. Biol., 114, 317-325. https://doi.org/ 10.1007/BFoo349534.

Darriba, D., Taboada, G.L., Doallo, R. \& Posada, D. (2012) jModelTest 2: more models, new heuristics and parallel computing. Nat. Methods, 9, 772. https://doi.org/10.1038/nmeth.2109.

Di Camillo, C.G., Bavestrello, G., Valisano, L. \& Puce, S. (2008) Spatial and temporal distribution in a tropical hydroid assemblage. J. Mar. Biol. Assoc. U.K., 88, 1589-1599. https://doi.org/10.1017/ Soo253154080o2981.

Drummond, A.J., Suchard, M.A., Xie, D. \& Rambaut, A. (2012) Bayesian phylogenetics with BEAUti and the BEAST 1.7. Mol. Biol. Evol., 29, 1969-1973. https://doi.org/10.1093/molbev/msso75.

Edwards, C. (1973) Contributory thoughts on form, function, habitat and classification in hydroids and hydromedusae. Publ. Seto Mar. Biol. Lab., 2o, 11-22. https://doi.org/10.5134/175793.

Ezard, T., Fujisawa, T. \& Barraclough, T.G. (2009) SPLITS: Species limits by threshold statistics. $\mathrm{R}$ Package Version 1.0-11. http://r-forge.r-project. org/projects/splits/.

Fontaneto, D., Flot, J.F. \& Tang, C.Q. (2015) Guidelines for DNA taxonomy, with a focus on 
the meiofauna. Mar. Biodivers., 45, 433-451. https://doi.org/10.1007/s12526-015-0319-7.

Fraser, C.M. (1938) Hydroids of the 1934 Allan Hancock Pacific Expedition. Allan Hancock Pacific Expeditions, 4, 1-105.

Galea, H.R. (2008) On a collection of shallowwater hydroids (Cnidaria: Hydrozoa) from Guadeloupe and Les Saintes, French Lesser Antilles. Zootaxa, 1878, 1-54. https://doi. org/10.11646/zootaxa.1878.1.1.

Galea, H.R. (2013) New additions to the shallowwater hydroids (Cnidaria: Hydrozoa) of the French Lesser Antilles: Martinique. Zootaxa, 3686, 1-5o. https://doi.org/10.11646/ zootaxa.3686.1.1.

Geyer, C. (1832) Zuträge zur Sammlung exotischer Schmetterlinge, bestehend in Bekanntmachung einzelner Geschlechter neuer oder seltener nichteuropäischer Arten. (Fortsetzung des Hübner'schen Werkes). Viertes Hundert. Augsburg. https://doi.org/10.5962/bhl.title.12439.

Haeckel, E. (1879) Das system der medusen: erster theil einer monographie der medusen. G. Fischer, Jena. https://dx.doi.org/10.5962/bhl. title.46856.

Hamond, R. (1974) Some medusae and other hydrozoa from the Indian Ocean and the Bass Strait. J. Nat. Hist., 8, 549-561. https://doi. org/10.1080/00222937400770471.

Hargitt, C.W. (1904) Notes on a Hitherto Undescribed Hydroid from Long Island Sound. Biol. Bull., 7, 251-253. https://doi.org/10.2307/ 1535712.

Hartlaub, C. (1907) XII Craspedote Medusen. Teil 1, Lieferung 1. Codoniden und Cladonemiden. Nord. Plankton, 6, 1-135.

Heled, J. \& Drummond, A.J. (2009) Bayesian inference of species trees from multilocus data. Mol. Biol. Evol., 27, 570-58o. https://doi. org/10.1093/molbev/msp274.

Hirohito, E.S. (1988) The hydroids of Sagami Bay. Publications of the Biolological Laboratory, Imperial Household, Tokyo.
Huang, J.-Q., Xu, Z.-Z., Lin, M. \& Gua, D.-H. (2015) Two New Species of Suborder Tubulariida from the South China Sea (Anthomedusae, Capitata). J. Xiamen Univ. (Nat. Sci.), 54, 824-828. https:// doi.org/10.6o43/j.issn.0438-0479.2015.06.o13.

Hunter, J.D. (2007) Matplotlib: A 2D graphics environment. IEEE Ann. Hist. Comput., 9, 90-95. https://doi.org/10.1109/MCSE.2007.55.

Jarms, G. \& Tiemann, H. (1996) On a new hydropolyp without tentacles, Microhydrula limopsicola n. sp., epibiotic on bivalve shells from the Antarctic. Sci. Mar., 6o, 109-115.

Just, J., Kristensen, R.M. \& Olesen, J. (2014) Dendrogramma, new genus, with two new nonbilaterian species from the marine bathyal of southeastern Australia (Animalia, Metazoa incertae sedis) with similarities to some medusoids from the Precambrian Ediacara. PLoS One, 9, e1o2976. https://doi.org/10.1371/ journal.pone.0102976.

Kapli, P., Lutteropp, S., Zhang, J., Kobert, K., Pavlidis, P., Stamatakis, A. \& Flouri, T. (2017) Multi-rate Poisson tree processes for singlelocus species delimitation under maximum likelihood and Markov chain Monte Carlo. Bioinformatics, 33, 1630-1638. https://doi. org/10.1093/bioinformatics/btxo25.

Katoh, K. \& Standley, D.M. (2013) MAFFT multiple sequence alignment software version 7 : improvements in performance and usability. Mol. Biol. Evol., 30, 772-780. https://doi. org $/ 10.1093 / \mathrm{molbev} / \mathrm{msto1o}$.

Kearse, M., Moir, R., Wilson, A., Stones-Havas, S., Cheung, M., Sturrock, S., Buxton, S., Cooper, A., Markowitz, S., Duran, C., Thierer, T., Ashton, B., Meintjes, P. \& Drummond, A. (2012) Geneious basic: an integrated and extendable desktop software platform for the organization and analysis of sequence data. Bioinformatics, 28, 1647-1649. https://doi.org/10.1093/bioinformatics/ btsig9.

Kramp, P.L. (1928) Papers from Dr. Mortensen's Pacific Expeditions 1914-1916, XLIII. 
Hydromedusae 1. Anthomedusae. Vidensk. Medd. fra Dansk. Naturh. Foren., 85, 27-64.

Kramp, P.L. (1942) The Godthaab Expedition, 1928: Medusæ. Medd. Grønl., 81, 1-168.

Kramp, P.L. (1955) The medusae of the tropical west coast of Africa. Atlantide Rep., 3, 239-324.

Kramp, P.L. (1965) The hydromedusae of the Pacific and Indian Oceans. Dana Rep., 63, 1-162.

Kramp, P.L. (1968) The hydromedusae of the Pacific and Indian oceans. Sections II and III. Dana Rep., 72, 1-200.

Kühn, A.L. \& Haase, M. (2020) QUIDDICH: QUick IDentification of DIagnostic CHaracters. J. Zool. Syst. Evol. Res., 58, 22-26. https://doi.org/10.1111/ jzs.12347.

Kumar, S., Stecher, G., Li, M., Knyaz, C. \& Tamura, K. (2018) MEGA X: molecular evolutionary genetics analysis across computing platforms. Mol. Biol. Evol., 35, 1547-1549. https://doi.org/10.1093/ molbev/msyog6.

Lanfear, R., Calcott, B., Ho, S.Y. \& Guindon, S. (2012). PartitionFinder: combined selection of partitioning schemes and substitution models for phylogenetic analyses. Mol. Biol. Evol., 29, 1695-1701. https://doi.org/10.1093/molbev/ msso2o.

Leigh, J.W. \& Bryant, D. (2015) popart: full-feature software for haplotype network construction. Methods Ecol. Evol., 6, 1110-1116. https://doi. org/10.1111/2041-210X.12410.

Maddison, W.P. \& Maddison, D.R. (2006) Mesquite: a modular system for evolutionary analysis. http://www.mesquiteproject.org.

Maggioni, D., Montano, S., Seveso, D. \& Galli, P. (2016) Molecular evidence for cryptic species in Pteroclava krempfi (Hydrozoa, Cladocorynidae) living in association with alcyonaceans. Syst. Biodivers., 14, 484-493. https://doi.org/10.1080/ 14772000.2016.1170735.

Maggioni, D., Galli, P., Berumen, M.L., Arrigoni, R., Seveso, D. \& Montano, S. (2017) Astrocoryne cabela, gen. nov. et sp. nov. (Hydrozoa: Sphaerocorynidae), a new sponge-associated hydrozoan. Invert. Syst., 31, 734-746. https://doi. org/10.1071/IS16og1.
Maggioni, D., Arrigoni, R., Galli, P., Berumen, M.L., Seveso, D. \& Montano, S. (2018) Polyphyly of the genus Zanclea and family Zancleidae (Hydrozoa, Capitata) revealed by the integrative analysis of two bryozoan-associated species. Contr. Zool., 87, 87-104. https://doi.org/10.1163/ 18759866-08702003.

Maggioni, D., Arrigoni, R., Seveso, D., Galli, P., Berumen, M.L., Denis, V., Hoeksema, B.W., Huang, D., Manca, F., Pica, D., Puce, S., Reimer, J.D. \& Montano, S. (2020a) Evolution and biogeography of the Zanclea-Scleractinia symbiosis. Coral Reefs, 1-17. https://doi.org/ 10.1007/soo338-020-02010-9.

Maggioni, D., Schiavo, A., Ostrovsky, A.N., Seveso, D., Galli, P., Arrigoni, R., Berumen, M.L., Benzoni, F. \& Montano, S. (2020b) Cryptic species and host specificity in the bryozoan-associated hydrozoan Zanclea divergens (Hydrozoa, Zancleidae). Mol. Phylogenet. Evol., 151, 106893. https://doi.org/10.1016/j.ympev.2020.106893.

Maggioni, D., Montano, S., Voigt, O., Seveso, D. \& Galli, P. (2020c) A mesophotic hotel: the octocoral Bebryce cf. grandicalyx as a host. Ecology, 101, e0295o. https://doi.org/10.1002/ ecy.295o.

Maggioni, D., Saponari, L., Seveso, D., Galli, P., Schiavo, A., Ostrovsky, A.N. \& Montano, S. (2020d) Green fluorescence patterns in closely related symbiotic species of Zanclea (Hydrozoa, Capitata). Diversity, 12, 78. https:// doi.org/10.339o/d12020078.

Maggioni, D., Garese, A., Huang, D., Hoeksema, B.W., Arrigoni, R., Seveso, D., Galli, P., Berumen, M.L., Montalbetti, E., Pica, D., Torsani, F. \& Montano, S. (2021) Diversity, host specificity and biogeography in the Cladocorynidae (Hydrozoa, Capitata), with description of a new genus. Cladistics. https://doi.org/10.1111/ cla.1248o.

Mayer, A.G. (1900) Some medusae from the Tortugas, Florida. Bull. Mus. Comp. Zool., 37, $13-82$.

Mayer, A.G. (1910) Medusae of the world. Hydromedusae, Vols. I \& II. Scyphomedusae, Downloaded from Brili. como4/26/2023 11:25:35AM via free access 
Vol III. Carnegie Institution, Washington. https://dx.doi.org/10.5962/bhl.title.

McCrady, J. (1859) Gymnopthalmata of Charleston harbor. Proc. Elliott Soc. Natur. Hist. Charleston, 1, 103-221.

Mendoza-Becerril, M.A., Simões, N. \& Genzano, G. (2018) Benthic hydroids (Cnidaria, Hydrozoa) from Alacranes Reef, Gulf of Mexico, Mexico. Bull. Mar. Sci., 94, 125-142. https://doi.org/ 10.5343/bms.2017.1072.

Menge, A. (1854) In: Koch, C.L. \& Berendt, C.G., Die im Bernstein befindlichen Crustaceen, Myriapoden, Arachniden und Apteren des Vorwelt. Berlin.

Mergner, H. \& Wedler, E. (1977) Ueber die Hydropolypenfauna des Roten Meeres und seiner Ausgänge. Meteor Forschungs-Ergebnisse, 24, 1-32.

Miglietta, M.P. \& Lessios, H.A. (2009) A silent invasion. Biol. Invasions, 11, 825-834. https://doi. org/10.1007/s10530-0o8-9296-o.

Miglietta, M.P., Odegard, D., Faure, B. \& Faucci, A. (2015) Barcoding techniques help tracking the evolutionary history of the introduced species Pennaria disticha (Hydrozoa, Cnidaria). PLoS One, 10, eo144762. https://doi.org/10.1371/ journal.pone.0144762.

Miglietta, M.P., Piraino, S., Pruski, S., Alpizar Gonzalez, M., Castellanos, S., Jeronimo, S., Lawley, J.W., Maggioni, D., Martell, L., Matsumoto, Y., Moncada, A., Nagale, P., Phongphattarawat, S., Sheridan, C., Soto, J., Sukhoputova, A. \& Collin, R. (2018) An integrative identification guide to the Hydrozoa (Cnidaria) of Bocas del Toro, Panama. Neotrop. Biodivers., 4, 103-113. https://doi.org/10.1080/237 66808.2018.1488656.

Miglietta, M.P., Maggioni, D. \& Matsumoto, Y. (2019) Phylogenetics and species delimitation of two hydrozoa (phylum Cnidaria): Turritopsis (McCrady, 1857) and Pennaria (Goldfuss, 1820). Mar. Biodivers., 49, 1085-1100. https://doi. org/10.1007/s12526-018-o891-8.

Millard, N.A.H. (1975) Monograph on the Hydroida of southern Africa. Ann. S. Afr. Mus., 68, 1-513.
Miller,M.A.,Pfeiffer,W.\&Schwartz,T.(2010)Creating the CIPRES Science Gateway for inference of large phylogenetic trees. In: Proceedings of the Gateway Computing Environments Workshop. https://doi.org/10.1109/GCE.2010. 5676129 .

Miranda, L.S., Collins, A.G. \& Marques, A.C. (2010) Molecules clarify a cnidarian life cycle -the "hydrozoan" Microhydrula limopsicola is an early life stage of the staurozoan Haliclystus antarcticus. PLoS One, 5, e1o182. https://doi. org/10.1371/journal.pone.oo10182.

Montano, S., Maggioni, D., Galli, P. \& Hoeksema, B.W. (2017a) A cryptic species in the Pteroclava krempfi species complex (Hydrozoa, Cladocorynidae) revealed in the Caribbean. Mar. Biodivers., 47, 83-89. https://doi.org/10.1007/ S12526-016-0555-5.

Montano, S., Fattorini, S., Parravicini, V., Berumen, M.L., Galli, P., Maggioni, D., Arrigoni, R., Seveso, D. \& Strona, G. (2017b) Corals hosting symbiotic hydrozoans are less susceptible to predation and disease. Proc. Royal Soc. B Biol. Sci., 284, 20172405. https://doi.org/10.1098/ rspb.2017.2405.

Montano, S., Reimer, J.D., Ivanenko, V.N., GarcíaHernández, J.E., van Moorsel, G.W., Galli, P. \& Hoeksema, B.W. (2020) Widespread occurrence of a rarely known association between the hydrocorals Stylaster roseus and Millepora alcicornis at Bonaire, southern Caribbean. Diversity, 12, 218. https://doi.org/10.339o/ di2o6o218.

Montenegro, J., Hoeksema, B.W., Santos, M.E., Kise, H. \& Reimer, J. D. (2020) Zoantharia (Cnidaria: Hexacorallia) of the Dutch Caribbean and one new species of Parazoanthus. Diversity, 12, 190. https://doi.org/10.339o/d1205019o.

Nagale, P. \& Apte, D. (2014) Intertidal hydroids (Cnidaria: Hydrozoa: Hydroidolina) from the Gulf of Kutch, Gujarat, India. Mar. Biodivers. Rec., 7, el16. https://doi.org/10.1017/ S1755267214001146.

Nawrocki, A.M., Schuchert, P. \& Cartwright, P. (2010) Phylogenetics and evolution of Capitata Downloaded from Brill.com04/26/2023 I1:25:35AM via free access 
(Cnidaria: Hydrozoa), and the systematics of Corynidae. Zool. Scr., 39, 290-304. https://doi. org/10.1111/j.1463-6409.2009.00419.x.

O'Hara, T.D., Hugall, A.F., MacIntosh, H., Naughton, K.M., Williams, A. \& Moussalli, A. (2016) Dendrogramma is a siphonophore. Curr. Biol., 26, R457-R458. https://doi.org/10.1016/j. cub.2016.04.051.

Pagès, F. \& Bouillon, J. (1997) A redescription of Paragotoea bathybia Kramp 1942 (Hydroidomedusae: Corymorphidae) with a new diagnosis for the genus Paragotoea. Sci. Mar., 61, 487-493.

Paradis, E., Claude, J. \& Strimmer, K. (2004) APE: analyses of phylogenetics and evolution in $\mathrm{R}$ language. Bioinformatics, 20, 289-29o. https:// doi.org/10.1093/bioinformatics/btg412.

Petersen, K.W. (1990) Evolution and taxonomy in capitate hydroids and medusae (Cnidaria: Hydrozoa). Zool. J. Linn. Soc., 100, 101-231. https://doi.org/10.1111/j.1096-3642.199o. tbo1862.x.

Pfeffer, G. (1889) Zur fauna von Süd-Georgien. Jahrb. Hamburg. Wiss. Anst., 6, 37-55.

Pictet, C. (1893) Étude sur les hydraires de la Baie d'Amboine. Rev. Suisse Zool., 1, 1-64. https://doi. org/10.5962/bhl.part.3743.

Pons, J., Barraclough, T.G., Gomez-Zurita, J., Cardoso, A., Duran, D.P., Hazell, V. \& Vogler, A.P. (2006) Sequence based species delimitation for the DNA taxonomy of undescribed insects. Syst. Biol., 55, 595-6o9. https://doi. org/10.108o/10635150600852011.

Puillandre, N., Brouillet, S. \& Achaz, G. (2021) ASAP: assemble species by automatic partitioning. Mol. Ecol. Res., 21, 6o9-62o. https://doi.org/ 10.1111/1755-0998.13281.

Pyataeva, S.V., Hopcroft, R.R., Lindsay, D.J. \& Collins, A.G. (2016) DNA barcodes unite two problematic taxa: the meiobenthic Boreohydra simplex is a life-cycle stage of Plotocnide borealis (Hydrozoa: Aplanulata). Zootaxa, 415o, 85-92. https://doi.org/10.11646/zootaxa.4150.1.5.
R Core Team. (2020) R:Alanguage and environment for statistical computing. R Foundation for Statistical Computing, Vienna, Austria. https:// www.R-project.org/.

Rambaut, A., Suchard, M.A., Xie, D. \& Drummond, A.J. (2014) Tracer vi.6. http://beast.bio.ed.ac.uk/ Tracer.

Rees, W.J. (1957) Evolutionary trends in the classification of capitate hydroids and medusae. Bull. Br. Mus. Nat. Hist. Zool., 4, 455-534.

Reid, N.M. \& Carstens, B. C. (2012) Phylogenetic estimation error can decrease the accuracy of species delimitation: a Bayesian implementation of the general mixed Yule-coalescent model. BMC Evol. Biol., 12, 196. https://doi. org/10.1186/1471-2148-12-196.

Reimer J.D., Wee, H.B., García-Hernández, J.E. \& Hoeksema, B.W. (2018) Zoantharia (Anthozoa: Hexacorallia) abundance and associations with Porifera and Hydrozoa across a depth gradient on the west coast of Curaçao. Syst. Biodivers., 16, 820-83o. https://doi.org/10.1080/14772000.2018 .1518936 .

Ronquist, F., Teslenko, M., van der Mark, P., Ayres, D.L., Darling, A., Höhna, S. \& Huelsenbeck, J.P. (2012) MrBayes 3.2: efficient Bayesian phylogenetic inference and model choice across a large model space. Syst. Biol., 61, 539542. https://doi.org/10.1093/sysbio/syso29.

Schmidt, H.E. (1973) Die Hydromedusen (Hydrozoa: Coelenterata) des Roten Meeres und seiner angrenzenden Gebiete. Meteor Forschungs-Ergebnisse, 15, 1-35.

Schuchert, P. (2005) Species boundaries in the hydrozoan genus Coryne. Mol. Phylogenet. Evol., 36, 194-199. https://doi.org/10.1016/j. ympev.2005.03.021.

Schuchert, P. (2010) The European athecate hydroids and their medusae (Hydrozoa, Cnidaria): Capitata part 2. Rev. Suisse Zool., 117, 337-555. https://doi.org/10.5962/bhl.part.117793. Schuchert, P., Hosia, A. \& Leclère, L. (2017) Identification of the polyp stage of three 
leptomedusa species using DNA barcoding. Rev. Suisse Zool., 124, 167-182. https://doi. org/10.5281/zenodo.322675.

Schuchert, P. (2018) DNA barcoding of some Pandeidae species (Cnidaria, Hydrozoa, Anthoathecata). Rev. Suisse Zool., 125, 101-127. https://doi.org/10.5281/zenodo.1196o29.

Schuchert, P. \& Collins, R. (2021). Hydromedusae observed during night dives in the Gulf Stream. Rev. Suisse Zool., 128, 237-356. https://doi. org/10.35929/RSZ.oo49.

Segura-Puertas, L. (1984) Morfología, sistemática y zoogeografía de las medusas (Cnidaria, Hydrozoa y Scyphozoa) del Pacífico Trópical Oriental. Inst. Cienc. Mar Limnol., Univ. Nac. Autón. México, Publicación Especial, 8, 1-320.

Stamatakis, A. (2014) RAxML version 8: a tool for phylogenetic analysis and post-analysis of large phylogenies. Bioinformatics, 30, 13121313. https://doi.org/10.1093/bioinformatics/ btuo33.

Swofford, D.L. (2003) PAUP. Phylogenetic Analysis Using Parsimony (and other methods). Version 4. Sinauer Associates, Sunderland, Massachusetts.

Talavera, G. \& Castresana, J. (2007) Improvement of phylogenies after removing divergent and ambiguously aligned blocks from protein sequence alignments. Syst. Biol., 56, 564-577. https://doi.org/10.108o/10635150701472164.

Uchida, T. (1927) Studies on Japanese hydromedusae. I. Anthomedusae. J. Fac. Sci. Imp. Univ. Tokyo. IV. Zool., 1, 145-241.

Vannucci, M. \& Santhakumari, V. (1969) New records of Hydromedusae from the shelf area off the Kerala coast. J. Mar. Biol. Assoc. India, 11, $40-43$.

Villesen, P. (2007) FaBox: an online toolbox for fasta sequences. Mol. Ecol. Notes, 7, 965-968. https://doi.org/10.1111/j.1471-8286.2007.01821.x.

Wang, C., Xu, Z., Huang, J., Guo, D., Lin, M. \& Xia, Z . (2016) Taxonomic notes on Hydroidomedusae (Cnidaria) from South China Sea III: Family Rathkeidae and Zancleopsidae. Zool. Syst., 41, 392-403. https://doi.org/10.11865/zs.201644.

Warren, E. (1908) On a collection of hydroids, mostly from the Natal coast. Ann. Natal Gov. Mus., 1, 269-355.

Wedler, E. \& Larson, R. (1986) Athecate hydroids from Puerto Rico and the Virgin Islands. Stud. Neotrop. Fauna Environ., 21, 69-101. https://doi. org/10.108o/0165052860936o698.

Wörheide, G. \&Erpenbeck, D. (2007) DNA taxonomy of sponges-progress and perspectives. J. Mar. Biol. Assoc. U.K., 87, 1629-1633. https://doi. org/10.1017/Soo25315407058274.

$\mathrm{Xu}$, Z.Z. \& Huang, J.Q. (2004) A survey on Anthomedusae (Hydrozoa: Hydroidomedusae) from the Taiwan Strait with description of new species and new combinations. Acta Oceanol. Sin., 23, 549-562.

Yamada, M., \& Konno, K. (1973). Polyp and medusa of the hydroid Sphaerocoryne multitentaculata (Warren) from Japan. Publ. Seto Mar. Biol. Lab., 20, 103-109. https://doi.org/10.5134/175786.

RECEIVED: 8 JULY 2021 | REVISED AND ACCEPTED: 10 AUGUST 2021

EDITOR: R. VONK 